\title{
Associations of 5HTTLPR polymorphism with major depressive disorder and alcohol dependence: A systematic review and meta- analysis
}

\author{
Khine Zin Oo, ${ }^{1,2}$ Ye Kyaw Aung, ${ }^{1}$ Mark A. Jenkins ${ }^{1}$ and Aung Ko Win ${ }^{1}$ \\ ${ }^{1}$ Centre for Epidemiology and Biostatistics, Melbourne School of Population and \\ Global Health, The University of Melbourne, Parkville, Victoria, Australia. \\ ${ }^{2}$ The Park - Centre for Mental Health, Treatment, Research and Education, \\ Wacol, Queensland, Australia
}

\section{Corresponding Author:}

Aung Ko Win, Centre for Epidemiology and Biostatistics, Melbourne School of Population and Global Health, The University of Melbourne

Level 3, 207 Bouverie Street, VIC 3010, Australia

Phone: +61 39035 8238; Fax: +61 39349 5815; Email: awin@unimelb.edu.au

\section{Acknowledgements}

$\mathrm{KZO}$, MAJ and AKW were involved in the conception or design of the study. KZO, YKA and $\mathrm{AKW}$ were involved in literature search, review and data extraction. KZO and AKW conducted the data analysis. KZO drafted the first version of the manuscript. All authors were involved in interpretation of data, and revising the manuscript critically for important intellectual content and final approval of the version published.

\section{Declaration of Conflicting Interests}

The author(s) declared no potential conflicts of interest with respect to the research, authorship and/or publication of this article.

\section{Funding}

The author(s) disclosed receipt of the following financial support for the research, authorship, and/or publication of this article: This work was supported by Australian National Health and Medical Research Council Early Career Fellowship (AKW) and Senior Research Fellowship (MAJ). 


\begin{abstract}
Objective: The neurotransmitter serotonin is understood to control mood and drug response. Carrying a genetic variant in the serotonin transporter gene (5HTT) may increase the risk of major depressive disorder and alcohol dependence. Previous estimates of the association of the S allele of 5HTTLPR polymorphism with major depressive disorder and alcohol dependence have been inconsistent.
\end{abstract}

Methods: For the systematic review, we used PubMed MEDLINE and Discovery of The University of Melbourne to search for all relevant case-control studies investigating the associations of 5HTTLPR polymorphism with major depressive disorder and alcohol dependence. Summary odds ratios (ORs) and their 95\% confidence intervals (CIs) were estimated. To investigate whether year of publication, study population or diagnostic criteria used were potential sources of heterogeneity, we performed meta-regression analyses. Publication bias was assessed using Funnel plots and Egger's statistical tests.

Results: We included 23 studies of major depressive disorder without alcohol dependence containing 3392 cases and 5093 controls, and 11 studies of alcohol dependence without major depressive disorder containing 2079 cases and 2273 controls. The summary OR for homozygote carriers of the S allele of 5HTTLPR polymorphism compared with heterozygote and non-carriers combined (SS vs SL+LL genotype) was 1.33 (95\% CI 1.19-1.48) for major depressive disorder and 1.18 (95\% CI 1.01-1.38) for alcohol dependence. The summary OR per S allele of 5HTTLPR polymorphism was 1.16 (95\% CI 1.08-1.23) for major depressive disorder and 1.12 (95\% CI 1.01-1.23) for alcohol dependence. There was no evidence for publication bias of the studies included in our meta-analysis. 
Conclusions: Our meta-analysis confirms that individuals with the homozygous S allele of 5HTTLPR polymorphism are at increased risks of major depressive disorder as well as alcohol dependence. Further studies are required to investigate the association between 5HTTLPR polymorphism and the comorbidity of major depressive disorder and alcohol dependence as well as gene $\times$ environmental interactions.

Keywords: Serotonin transporter, 5HTTLPR polymorphism, depression, alcohol dependence, meta-analysis 


\section{INTRODUCTION}

Depression and alcohol dependence are multi-factorial, complex disorders influenced by both genetic and environmental factors; however, despite intensive research the aetiology remains unclear. Heritability has been estimated to be $37 \%$ for major depressive disorder (Sullivan et al., 2000) and 30-36\% for alcohol dependence (Pickens et al., 1991). The lifetime prevalence of major depressive disorder in the United States population has been estimated to be $5-12 \%$ for men and 10-25\% for women (Grant et al., 1994; Kessler et al., 1994; Regier et al., 1990), whereas prevalence of alcohol dependence is $20 \%$ for men and $12 \%$ for women (Kessler et al., 1994).

There have been several pathophysiological and genetic hypotheses proposed for aetiology of both depression and alcohol dependence. These include dysfunction of the neurotransmitters serotonin (5-hydroxytryptamine (5HT)), a monoamine known to affect anxiety, cognition, reward, emotion, drug responses and stress (Jans et al., 2006). Transport of serotonin from synaptic spaces into presynaptic neurons is regulated by serotonin transporter protein (5HTT), impairment of which has been implicated in susceptibility to many psychiatric disorders including depression and alcohol dependence. The gene encoding the serotonin transporter is called 5HTT (also known as SLC6A4) (Ramamoorthy et al., 1993). Two common variants, thought to affect regulation of the expression of 5HTT, have been identified in the 5HTT transporter-linked polymorphic region (5HTTLPR) of this gene (Heinz and Goldman, 2000; Lesch et al., 1996): S allele (484 base pairs long) and L allele (528 base pairs long) (Gelernter et al., 1997). For Caucasians, approximately 0.8-2.3\% are homozygous (SS genotype), 16-26\% are heterozygous (SL genotype), and 72-83\% are wild-type (LL genotype). The corresponding frequencies for African Americans are 6\%, 36\% and 58\% respectively (Hu et al., 2006; Wendland et al., 2008). 
Several studies have reported that individuals with depression are more likely to carry the S allele than those without depression (Collier et al., 1996; Gutierrez et al., 1998; Bellivier et al., 1998) while other studies showed no evidence of an association (Hoehe et al., 1998; Furlong et al., 1998; Frisch et al., 1999; Minov et al., 2001; Kunugi et al., 1997). Likewise, several studies have reported that individuals with alcohol dependence are more likely to carry S allele compared to those without alcohol dependence (Gorwood et al., 2000; Hallikainen et al., 1999; Hammoumi et al., 1999) whereas other studies found no evidence of an association (Ishiguro et al., 1999; Johann et al., 2003). Therefore, it is still a matter of controversy whether the S allele of 5HTTLPR polymorphism is associated with depression or alcohol dependence.

We have systematically reviewed all the previously published studies of the association between 5HTTLPR polymorphism with depression and alcohol dependence and conducted a meta-analysis to: (i) investigate separately for the strengths of associations of the S allele of the 5HTTLPR polymorphism with major depressive disorder without alcohol dependence and alcohol dependence without major depressive disorder, and (ii) estimate the proportion of major depressive disorder and alcohol dependence that might be due to the $\mathrm{S}$ allele of 5HTTLPR polymorphism.

\section{MATERIALS AND METHODS}

A systematic review was performed according to a predetermined protocol and reported in accordance with Meta-analysis Of Observational Studies in Epidemiology (MOOSE) guidelines (Stroup et al., 2000). This review was registered at the International Prospective Register of Systematic Reviews (PROSPERO registration number: CRD42015024911). 


\section{Search strategy}

We used PubMed MEDLINE and "Discovery" of the University of Melbourne Library to search for all the relevant studies of the association of 5HTTLPR polymorphism with major depressive disorder and alcohol dependence published before April 2014. The following Medical Subject Heading terms and keywords were used for search: "alcohol dependence" OR “alcoholism” OR “alcohol” OR “alcoholics” OR “depression” OR “depressive illness” OR “major depression” OR “depressive disorder” OR “unipolar disorder” AND “serotonin transporter polymorphism" OR "5HTTLPR" OR "SLC6A4". In addition, the reference lists of all relevant letters, articles, literature reviews and meta-analyses were reviewed to identify any articles not captured by the search engine strategy above. No restriction was imposed on language or year of publication. All articles were triaged for further assessment initially by title alone, then by abstract. Full manuscripts of every article with a relevant title and abstract were then sought for final assessment of eligibility.

\section{Eligibility criteria}

We included case-control studies that reported (i) the association of the S allele of 5HTTLPR polymorphism with depression or alcohol dependence, (ii) distribution of S and L alleles of 5HTTLPR polymorphism for both cases and controls and (iii) used one of the following criteria for diagnoses of major depressive disorder (cases with already established diagnosis of depression including recurrent episodes) and/or alcohol dependence: Diagnostic and Statistical Manual of Mental Disorders Fourth Edition (DSM-IV) (American Psychiatric Association, 1994), Diagnostic and Statistical Manual of Mental Disorders Third Edition Revised (DSM-III-R) (American Psychiatric Association, 1987), International Classification of Disease - 10th revision (ICD-10) (World Health Organization, 1992), Center for Epidemiologic 
Studies-Depression Scale (CES-D) (Radloff, 1977), Michigan Alcoholism Screening Test

(MAST) (Selzer, 1971), or Beck Depression Inventory (BDI) (Beck et al., 1961).

We excluded: (i) studies of cases with both depression and alcohol dependence; (ii) studies of children and adolescents; (iii) reviews or editorial or letters or non-peer-reviewed publications; (iv) studies that were not translated into English; or (v) studies that did not define cases and controls. All studies meeting the eligibility criteria were categorised into two groups: (i) major depressive disorder in the absence of alcohol dependence and (ii) alcohol dependence in the absence of major depressive disorder.

\section{Data extraction}

The following data were extracted from each study: title of the study, name of the first author, publication year, country where the study was performed, study design, inclusion and exclusion criteria of cases and controls, case ascertainment methods, number of cases and controls for each genotype and/or for each allele and odds ratios for the association between the $\mathrm{S}$ allele of 5HTTLPR polymorphism and the disorder. Cases with bipolar disorder were excluded from this meta-analysis. The literature search, assessment for eligibility, and data extraction were independently undertaken by two investigators (KZO and YKA) using a standardised approach. Any inconsistencies between them was identified by the third investigator (AKW) and resolved by consensus.

\section{Statistical Analysis}

The summary odds ratios (ORs) and their 95\% confidence intervals (CIs) were estimated for associations of the S allele of 5HTTLPR polymorphism with major depressive disorder and alcohol dependence. Both random effects and fixed effect models were fitted. We estimated associations for different inheritance modes of the S allele: recessive (SS vs. SL and LL); 
dominant (SS+SL vs. LL); and codominant (separately for SS and SL vs. LL). We also estimated OR per $\mathrm{S}$ allele, i.e. a linear association on the log scale.

To test the influence of individual studies on the summary estimates, we omitted data from each study one at a time and repeated the analysis. To estimate the heterogeneity between studies, the $I^{2}$ statistic was used (Higgins and Thompson, 2002). Meta-regression models were conducted including the year of publication (before and in 2000 vs. after 2000), study population (Caucasian vs. others), and diagnostic criteria used (DSM-IV vs. other criteria). To test for publication bias, Begg's funnel plot (Begg and Berlin, 1988) and Egger's statistical test (Egger et al., 1997) were performed. All statistical tests were two-sided, and all analysis was performed using STATA 13.0 (StataCorp, 2013).

Assuming the causal relationship of the homozygous S allele of 5HTTLPR polymorphism with major depressive disorder and/or alcohol dependence, the proportion of the diseases attributable to the homozygous S allele of 5HTTLPR polymorphism for general population was calculated using the formula:

$$
\mathrm{PAR}=\frac{\mathrm{P}(\mathrm{OR}-1)}{\mathrm{P}(\mathrm{OR}-1)+1}
$$

where PAR was population attributable risk, $\mathrm{P}$ was prevalence of the homozygous $\mathrm{S}$ allele of 5HTTLPR polymorphism (assumed to be $26 \%$ ), and OR was the summary odds ratio estimated from this study. 


\section{RESULTS}

Of the 1527 papers identified by the literature search, we excluded 1359 based on the title and abstract as they appeared not to be relevant to this systematic review. Of the 168 studies retrieved for full assessment of eligibility, 34 met the eligibility criteria and were included in the meta-analyses (Figure 1). Recruitment methods, selections and ages of cases and controls for each study are summarised in Table 1. Of these studies, 24 were conducted in Europe, two in the USA, and eight in other countries, and all were published between 1996 and 2009. Most of the studies used clinic-based controls or controls via convenient sampling while only a few studies used population-based controls but they did not describe the recruitment methods in details (Minov et al., 2001; Hickie et al., 2007; Gokturk et al., 2008).

5HTTLPR polymorphism and major depressive disorder

We identified 23 case-control studies reporting the association between the $\mathrm{S}$ allele of 5HTTLPR polymorphism and major depressive disorder without alcohol dependence. When combined, there were a total of 3392 cases of major depressive disorder of whom $25 \%(n=$ 834) had SS genotype, 46\% $(n=1568)$ had SL genotype, and 29\% $(n=990)$ had LL genotype. Of the total 5093 controls, $22 \%(n=1121)$ had SS genotype, $48 \%(n=2438)$ had SL genotype, and 30\% $(n=1534)$ had LL genotype (Table 2$)$. The estimated fixed effect summary OR of major depressive disorder was 1.33 (95\% CI 1.19-1.48) for recessive inheritance of the S allele (Supplementary Figure 1), and 1.12 (95\% CI 1.01-1.24) for dominant inheritance (Supplementary Figure 2) with no or low heterogeneity between studies (Table 3). Compared with non-carriers of the S allele, the summary OR of major depressive disorder was estimated to be 1.36 (95\% CI 1.19-1.56) for homozygous carriers of the S allele (Supplementary Figure 3 ) and 1.03 (95\% CI 0.93-1.15) for heterozygous carriers (Supplementary Figure 4). The 
summary OR of major depressive disorder per S allele of 5HTTLPR polymorphism was 1.16 (95\% CI 1.08-1.23) (Supplementary Figure 5).

5HTTLPR polymorphism and alcohol dependence

We identified 11 case-control studies reporting the association between the $\mathrm{S}$ allele of 5HTTLPR polymorphism and alcohol dependence without major depressive disorder. When combined, there were a total of 2079 cases of alcohol dependence of whom $41 \%(n=854)$ had SS genotype, $38 \%(n=793)$ had SL genotype, and 21\% $(n=432)$ had LL genotype. Of the total 2273 controls, $32 \%(n=720)$ had SS genotype, $42 \%(n=949)$ had SL genotype, and 21\% $(n=604)$ had LL genotype (Table 2$)$. The estimated fixed effect summary OR of alcohol dependence was 1.18 (95\% CI 1.01-1.38) for recessive inheritance of the S allele (Supplementary Figure 1) and 1.11 (95\% CI 0.94-1.32) for dominant inheritance (Supplementary Figure 2) with low heterogeneity between studies (Table 3). Compared with non-carriers of the S allele, the summary OR of alcohol dependence was estimated to be 1.33 (95\% CI 1.06-1.66) for homozygous carriers of the S allele (Supplementary Figure 3) and 1.02 (95\% CI 0.86-1.23) for heterozygous carriers (Supplementary Figure 4). The summary OR of alcohol dependence per S allele of 5HTTLPR polymorphism was 1.12 (95\% CI 1.01-1.23) (Supplementary Figure 5).

Meta-regression and publication bias

There were no major changes in the direction of summary estimates when any individual study was omitted at a time. Meta-regression models showed that associations of the S allele of 5HTTLPR polymorphism with major depressive disorder or alcohol dependence did not substantially change after adjusting for the year of publication, study population, and diagnostic criteria used (Table 4). 
Funnel plots for both major depressive disorder studies and alcohol dependence studies did not provide any evidence of publication bias (Figure 2). Also, there was no statistical evidence of publication bias ( $\mathrm{p}=0.12$ for major depressive disorder studies and $\mathrm{p}=0.10$ for alcohol dependence studies).

Population attributable risk

The population attributable risks were estimated to be $7.7 \%$ (95\% CI $4.5-11.1 \%)$ for major depressive disorder and 4.5\% (95\% CI 0.3-8.8\%) for alcohol dependence.

\section{DISCUSSION}

Our meta-analysis has shown that the homozygous and heterozygous carriers of the $\mathrm{S}$ allele of 5HTTLPR polymorphism are at increased risk of major depressive disorder and that homozygous carriers are at increased risk of alcohol dependence. There was insufficient evidence to conclude that heterozygous carriers have an increased risk of alcohol dependence. Our estimated summary ORs of disease risk per S allele of 5HTTLPR polymorphism support a dose-response relationship with both major depressive disorder and alcohol dependence.

To our knowledge, there have been five previous meta-analyses investigating the association between 5HTTLPR polymorphism and major depressive disorder (Clarke et al., 2010; Kiyohara and Yoshimasu, 2010; Lasky-Su et al., 2004; Lotrich and Pollock, 2004; Anguelova et al., 2003). Three meta-analyses reported no statistical evidence for an association

with major depressive disorder (Lasky-Su et al., 2004; Lotrich and Pollock, 2004; Anguelova et al., 2003). However, Anguelova et al. (2003) suggested that further studies were warranted to investigate variation at $5 H T T$ at the level of allelic subtypes as different allelic subtypes have different transcriptional activity. Consistent with our results, Clarke et al. (2010) reported an 
increased risk of major depressive disorder for carriers of SS genotype compared with carriers of SL or LL genotype (OR=1.16, 95\% CI 1.08-1.24) and Kiyohara and Yoshimasu (2010) reported an increased risk of major depressive disorder for Caucasian carriers of SS genotype compared with carriers of LL genotype (OR=1.41, 95\% CI 1.15-1.72). However, none of the previous meta-analyses considered that heterozygous carriers of the $\mathrm{S}$ allele might be at increased risk because they all compared homozygous carriers of the $\mathrm{S}$ allele with heterozygous carriers and/or non-carriers. In our meta-analysis, we observed evidence for both homozygous and heterozygous carriers of the S allele of 5HTTLPR polymorphism associated with an increased risk of major depressive disorder.

A previous meta-analysis (Feinn et al., 2005) studying the association between 5HTTLPR polymorphism and alcohol dependence estimated the odds ratio for homozygous carriers of the S allele to be 1.18 (95\% CI 1.03-1.33) but they did not estimate the association for heterozygous carriers. Similar to their result, our meta-analysis showed marginally significant evidence for a positive association between the homozygous carriers of the $\mathrm{S}$ allele of 5HTTLPR polymorphism and alcohol dependence.

The population attributable risks suggest that, if the observed associations are due to a causal relationship, then approximately 1 in 20 cases of major depressive disorder in the general population is attributable to the homozygous S allele of 5HTTLPR polymorphism and about 1 in 30 cases of alcohol dependence in the general population is attributable to the homozygous S allele.

A complication in elucidating the role of this polymorphism on the risk of major depressive disorder and alcohol dependence is their comorbidity. Compared with a person without alcohol dependence, a person with prior or current alcohol dependence has a four-fold 
increased risk of major depressive disorder (Hasin and Grant, 2002), and longer duration of major depressive disorder (Mueller et al., 1994). Therefore, most previous studies of this polymorphism have studied participants with either depression or alcohol dependence alone. Given that all the studies of major depressive disorder in our current review excluded individuals with alcohol dependence, our findings of an increased risk of depression associated with the SS or SL genotype of 5HTTLPR polymorphism was less likely to be confounded by alcohol dependence. Likewise, given that all studies of alcohol dependence excluded individuals with major depressive disorder, our finding of an increased risk of alcohol dependence associated with the SS genotype of 5HTTLPR polymorphism was less likely to be confounded by major depressive disorder. However, the case-control studies included in this review are unlikely to adequately deal with confounding from lifetime comorbidity between alcohol disorders and major depressive disorder. This is because even if studies attempted to control for or exclude the other condition, lifetime comorbidity is likely to have been underestimated because of inaccurate recall (Moffitt et al., 2010).

Effectiveness studies of selective serotonin reuptake inhibitors (SSRIs) had supported a causal relationship between the S allele and depression (Jones and Blackburn, 2002; Snow et al., 2000; Williams et al., 2000). The effectiveness of SSRIs for treatment of depression was greater in carriers of homozygous L allele when compared with carriers of homozygous S allele (Smeraldi et al., 1998; Zanardi et al., 2000). In another meta-analysis that investigated the association of 5HTTLPR with SSRI efficacy, it was again demonstrated that the L allele of 5HTTLPR polymorphism has association with better response to antidepressant (Serretti et al., 2007). These results of the S allele of 5HTTLPR being associated with poor SSRI efficacy supported the hypothesis that serotonin dysregulation involves in the aetiology of depression (Serretti et al., 2007). Brain-imaging studies have shown association between serotonin deficits 
and alcoholism (Cloninger, 1995; Tiihonen et al., 1997), suggesting that 5HTTLPR

polymorphism alters the serotonin expression and affects the neurotransmission of serotonin in the nervous system. Moreover, 5HTTLPR polymorphism has been shown to be associated with high alcohol intake (Hinckers et al., 2006; Covault et al., 2007).

Several studies have also shown evidence for gene $\times$ environmental interactions for depression (Caspi et al., 2003) as well as alcohol dependence (Dick and Kendler, 2012; Hines et al., 2015). Individuals with the SL/LL genotype of 5HTTLPR are more likely to have depression in relation to stressful life events than those with the LL genotype (Kendler et al., 2005; Caspi et al., 2003). Individuals with the SS genotype of 5HTTLPR are more likely to have frequent drinking and heavy drinking as well as drug use if they experience multiple negative life events (Covault et al., 2007). In contrast, the Mannheim Study of Children at Risk reported that German young adults with the LL genotype who have exposed to early psychosocial adversity are more likely to have hazardous drinking than those with the LL genotype not exposed to early adversity or those with the SL/SS genotype regardless of adversity (Laucht et al., 2009). Accordingly, the genetic model associated with the interaction has been inconsistent across studies, and the primary outcomes and measures of the experience of stress have varied considerably (Young-Wolff et al., 2011). However, our current review was not able to examine 5HTTLPR polymorphism $\times$ environmental interactions.

Our meta-analysis was limited to the fact that unpublished data of association between 5HTTLPR and major depressive disorder and/or alcohol dependence were not included. However, given that the funnel plot and statistical tests showed no evidence of publication bias, the impact of unpublished findings is less likely. Even though the possible potential sources of heterogeneity (year of publication, study populations, and diagnostic criteria used) that we investigated were not found to be significant, other possible residual sources for heterogeneity 
such as onset and duration of alcohol dependence, and other comorbid conditions or complications (including suicide/suicidal ideation, aggression and anti-social behaviours) could not be assessed in this meta-analysis. Controls from most of the studies included in this review were not individuals who were randomly recruited from the general population where cases were selected therefore the study results might be biased.

Overall, our review confirmed that individuals with the homozygous S allele of 5HTTLPR polymorphism are at increased risks of major depressive disorder as well as alcohol dependence. The variation seen in each individual study results is consistent with the subtle and environment dependent effect of 5HTTLPR polymorphism on disease risks. Further studies are required to investigate the association between 5HTTLPR polymorphism and the comorbidity of major depressive disorder and alcohol dependence as well as gene $\times$ environmental interactions.

\section{REFERENCES}

American Psychiatric Association. (1987) Diagnostic and Statistical Manual of Mental Disorders. Third Edition - Revised, Washington, DC: American Psychiatric Association.

American Psychiatric Association. (1994) Diagnostic and Statistical Manual of Mental Disorders. Fourth Edition, Washington, DC: American Psychiatric Association.

Anguelova M, Benkelfat C and Turecki G. (2003) A systematic review of association studies investigating genes coding for serotonin receptors and the serotonin transporter: I. Affective disorders. Mol Psychiatry 8: 574-591. 
Arias B, Catal·n R, GastÛ C, et al. (2003) 5-HTTLPR polymorphism of the serotonin transporter gene predicts non-remission in major depression patients treated with citalopram in a 12-weeks follow up study. J Clin Psychopharmacol 23: 563.

Beck AT, Ward CH, Mendelson M, et al. (1961) An inventory for measuring depression. Arch Gen Psychiatry 4: 561-571.

Begg CB and Berlin JA. (1988) Publication bias: a problem in interpreting medical data. $J R$ Stat Soc Series B Stat Methodol 151: 419-463.

Bellivier F, Henry C, Szoke A, et al. (1998) Serotonin transporter gene polymorphisms in patients with unipolar or bipolar depression. Neurosci Lett 255: 143-146.

Caspi A, Sugden K, Moffitt TE, et al. (2003) Influence of life stress on depression: moderation by a polymorphism in the 5-HTT gene. Science 301: 386-389.

Cervilla JA, Rivera M, Molina E, et al. (2006) The 5 HTTLPR s/s genotype at the serotonin transporter gene (SLC6A4) increases the risk for depression in a large cohort of primary care attendees: The PREDICT gene study. Am J Med Genet 141: 912-917.

Clarke H, Flint J, Attwood AS, et al. (2010) Association of the 5- HTTLPR genotype and unipolar depression: a meta-analysis. Psychol Med 40: 1767-1778.

Cloninger CR. (1995) The psychobiological regulation of social cooperation. Nat Med 1: 623625.

Collier D, Stober G, Li T, et al. (1996) A novel functional polymorphism within the promoter of the serotonin transporter gene: possible role in susceptibility to affective disorders. Mol Psychiatry 1: 453-460. 
Covault J, Tennen H, Armeli S, et al. (2007) Interactive effects of the serotonin transporter 5HTTLPR polymorphism and stressful life events on college student drinking and drug use. Biol Psychiatry 61: 609-616.

Dick DM and Kendler KS. (2012) The impact of gene-environment interaction on alcohol use disorders. Alcohol Res 34: 318-324.

Dorado P, Peñas-Lledó E, González A, et al. (2007) Increased risk for major depression associated with the short allele of the serotonin transporter promoter region (5 HTTLPR S) and the CYP2C9* 3 allele. Fundam Clin Pharmacol 21: 451-453.

Egger M, Smith GD, Schneider M, et al. (1997) Bias in meta-analysis detected by a simple, graphical test. Bmj 315: 629-634.

Feinn R, Nellissery M and Kranzler H. (2005) Meta analysis of the association of a functional serotonin transporter promoter polymorphism with alcohol dependence. Am J Med Genet 133: 79-84.

Frisch A, Postilnick D, Rockah R, et al. (1999) Association of unipolar major depressive disorder with genes of the serotonergic and dopaminergic pathways. Mol Psychiatry 4: 389-392.

Frodl T, Meisenzahl EM, Zill P, et al. (2004) Reduced hippocampal volumes associated with the long variant of the serotonin transporter polymorphism in major depression. Arch Gen Psychiatry 61: 177-183.

Furlong R, Ho L, Walsh C, et al. (1998) Analysis and meta-analysis of two serotonin transporter gene polymorphisms in bipolar and unipolar affective disorders. Am J Med Genet 81: 58-63. 
Gelernter J, Kranzler H and Cubells J. (1997) Serotonin transporter protein (SLC6A4) allele and haplotype frequencies and linkage disequilibria in African- and European-American and Japnese populations and in alcohol-dependent subjects. Hum Genet 101: 243-246.

Gokturk C, Schultze S, Nilsson K, et al. (2008) Serotonin transporter (5-HTTLPR) and monoamine oxidase (MAOA) promoter polymorphisms in women with severe alcoholism. Arch Womens Ment Health 11: 347-355.

Gorwood P, Batel P, Ades J, et al. (2000) Serotonin transporter gene polymorphisms, alcoholism, and suicidal behavior. Biol Psychiatry 48: 259-264.

Grant B, Harford T, Dawson D, et al. (1994) Prevalence of DSM-IV alcohol abuse and dependence: United States. Alcohol Health Res World 18: 243-248.

Gutierrez B, Pintor L, Gasto C, et al. (1998) Variability in the serotonin transporter gene and increased risk for major depression with melancholia. Hum Genet 103: 319-322.

Hallikainen T, Saito T, Lachman H, et al. (1999) Association between low activity serotonin transporter promoter genotype and early onset alcoholism with habitual impulsive violent behavior. Mol Psychiatry 4: 385-388.

Hammoumi S, Payen A, Favre JD, et al. (1999) Does the short variant of the serotonin transporter linked polymorphic region constitute a marker of alcohol dependence? Alcohol 17: 107-112.

Hasin D and Grant B. (2002) Major depression in 6050 former drinkers: association with past alcohol dependence. Arch Gen Psychiatry 59: 794-800. 
Hauser J, Leszczynska A, Samochowiec J, et al. (2003) Association analysis of the insertion/deletion polymorphism in serotonin transporter gene in patients with affective disorder. Eur Psychiatry 18: 129-132.

Heinz A and Goldman D. (2000) Genotype effects on neurodegeneration and neuroadaptation in monoaminergic neurotransmitter systems. Neurochem Int 37: 425-432.

Hickie IB, Naismith SL, Ward PB, et al. (2007) Serotonin transporter gene status predicts caudate nucleus but not amygdala or hippocampal volumes in older persons with major depression. J Affect Disord 98: 137-142.

Higgins J and Thompson SG. (2002) Quantifying heterogeneity in a meta analysis. Stat Med 21: $1539-1558$

Hinckers AS, Laucht M, Schmidt MH, et al. (2006) Low level of response to alcohol as associated with serotonin transporter genotype and high alcohol intake in adolescents. Biol Psychiatry 60: 282-287.

Hines LA, Morley KI, Mackie C, et al. (2015) Genetic and Environmental Interplay in Adolescent Substance Use Disorders. Curr Addict Rep 2: 122-129.

Hoefgen B, Schulze TG, Ohlraun S, et al. (2005) The power of sample size and homogenous sampling: association between the 5-HTTLPR serotonin transporter polymorphism and major depressive disorder. Biol Psychiatry 57: 247-251.

Hoehe MR, Wendel B, Grunewald I, et al. (1998) Serotonin transporter (5-HTT) gene polymorphisms are not associated with susceptibility to mood disorders. Am J Med Genet 81: 1-3. 
Hu XZ, Lipsky RH, Zhu G, et al. (2006) Serotonin transporter promoter gain-of-function genotypes are linked to obsessive-compulsive disorder. Am J Hum Genet 78: 815-826.

Ishiguro H, Saito T, Akazawa S, et al. (1999) Association between drinking-related antisocial behavior and a polymorphism in the serotonin transporter gene in a Japanese population. Alcohol Clin Exp Res 23: 1281-1284.

Jans L, Riedel W, Markus C, et al. (2006) Serotonergic vulnerability and depression: assumptions, experimental evidence and implications. Mol Psychiatry 12: 522-543.

Johann M, Bobbe G, Putzhammer A, et al. (2003) Comorbidity of alcohol dependence with attention-deficit hyperactivity disorder: differences in phenotype with increased severity of the substance disorder, but not in genotype (serotonin transporter and 5hydroxytryptamine-2c receptor). Alcohol Clin Exp Res 27: 1527-1534.

Jones BJ and Blackburn TP. (2002) The medical benefit of 5-HT research. Pharmacol Biochem Behav 71: 555-568.

Kendler KS, Kuhn JW, Vittum J, et al. (2005) The interaction of stressful life events and a serotonin transporter polymorphism in the prediction of episodes of major depression: a replication. Arch Gen Psychiatry 62: 529-535.

Kessler RC, McGonagle KA, Zhao S, et al. (1994) Lifetime and 12-month prevalence of DSMIII-R psychiatric disorders in the United States. Results from the National Comorbidity Survey. Arch Gen Psychiatry 51: 8-19.

Kim DK, Lim SW, Lee S, et al. (2000) Serotonin transporter gene polymorphism and antidepressant response. Neuroreport 11: 215-219. 
Kiyohara C and Yoshimasu K. (2010) Association between major depressive disorder and a functional polymorphism of the 5-hydroxytryptamine (serotonin) transporter gene: a meta-analysis. Psychiatr Genet 20: 49-58.

Konishi T, Calvillo M, Leng AS, et al. (2004) Polymorphisms of the dopamine D2 receptor, serotonin transporter, and $\mathrm{GABA}(\mathrm{A})$ receptor beta(3) subunit genes and alcoholism in Mexican-Americans. Alcohol 32: 45-52.

Kunugi H, Hattori M, Kato T, et al. (1997) Serotonin transporter gene polymorphisms: ethnic difference and possible association with bipolar affective disorder. Mol Psychiatry 2: $457-462$.

Lasky-Su JA, Faraone SV, Glatt SJ, et al. (2004) Meta-analysis of the association between two polymorphisms in the serotonin transporter gene and affective disorders. Am J Med Genet 133: 110-115.

Laucht M, Treutlein J, Schmid B, et al. (2009) Impact of psychosocial adversity on alcohol intake in young adults: moderation by the LL genotype of the serotonin transporter polymorphism. Biol Psychiatry 66: 102-109.

Lesch K-P, Bengel D, Heils A, et al. (1996) Association of anxiety-related traits with a polymorphism in the serotonin transporter gene regulatory region. Science 274: 15271531.

Lotrich FE and Pollock BG. (2004) Meta-analysis of serotonin transporter polymorphisms and affective disorders. Psychiatr Genet 14: 121-129. 
Matsushita S, Yoshino A, Murayama M, et al. (2001) Association study of serotonin transporter gene regulatory region polymorphism and alcoholism. Am J Med Genet 105: 446-450.

Mellerup E, Bennike B, Bolwig T, et al. (2001) Platelet serotonin transporters and the transporter gene in control subjects, unipolar patients and bipolar patients. Acta Psychiatr Scand 103: 229-233.

Minov C, Baghai TC, Schule C, et al. (2001) Serotonin-2A-receptor and -transporter polymorphisms: lack of association in patients with major depression. Neurosci Lett 303: 119-122.

Moffitt TE, Caspi A, Taylor A, et al. (2010) How common are common mental disorders? Evidence that lifetime prevalence rates are doubled by prospective versus retrospective ascertainment. Psychol Med 40: 899-909.

Mueller TI, Lavori PW, Keller MB, et al. (1994) Prognostic effect of the variable course of alcoholism on the 10-year course of depression. Am J Psychiatry 151: 701-706.

Ohara K, Nagai M, Tsukamoto T, et al. (1998) Functional polymorphism in the serotonin transporter promoter at the SLC6A4 locus and mood disorders. Biol Psychiatry 44: 550554.

Oliveira JR, Carvalho DR, Pontual D, et al. (2000) Analysis of the serotonin transporter polymorphism (5-HTTLPR) in Brazilian patients affected by dysthymia, major depression and bipolar disorder. Mol Psychiatry 5: 348-349.

Pickens R, Svikis D, McGue M, et al. (1991) Heterogeneity in the inheritance of alcoholism: A study of male and female twins. Arch Gen Psychiatry 48: 19-28. 
Preuss UW, Koller G, Soyka M, et al. (2001) Association between suicide attempts and 5HTTLPR-S-allele in alcohol-dependent and control subjects: further evidence from a German alcohol-dependent inpatient sample. Biol Psychiatry 50: 636-639.

Radloff LS. (1977) The CES-D Scale: A Self-Report Depression Scale for Research in the General Population. Applied Psychological Measurement 1: 385-401.

Ramamoorthy S, Bauman AL, Moore KR, et al. (1993) Antidepressant and cocaine sensitive human serotonin transporter: molecular cloning, expression and chromosomal localization. Proc Natl Acad Sci 90: 2542-2546.

Rees M, Norton N, Jones I, et al. (1997) Association studies of bipolar disorder at the human serotonin transporter gene (hSERT; 5HTT). Mol Psychiatry 2: 398-402.

Regier D, Farmer M, Rae D, et al. (1990) Comorbidity of mental disorders with alcohol and other drug abuse. Results from the Epidemiologic Catchment Area (ECA) study. JAMA 264: $2511-2518$

Sander T, Harms H, Lesch K, et al. (1997) Association analysis of a regulatory variation of the serotonin transporter gene with severe alcohol dependence. Alcohol Clin Exp Res 21: 1356-1359.

Selzer ML. (1971) The Michigan alcoholism screening test: the quest for a new diagnostic instrument. Am J Psychiatry 127: 1653-1658.

Serretti A, Kato M, De Ronchi D, et al. (2007) Meta-analysis of serotonin transporter gene promoter polymorphism (5-HTTLPR) association with selective serotonin reuptake inhibitor efficacy in depressed patients. Mol Psychiatry 12: 247-257. 
Serretti A, Lilli R, Lorenzi C, et al. (2002) Serotonin transporter gene (5-HTTLPR) and major psychoses. Mol Psychiatry 7: 95-99.

Smeraldi E, Zanardi R, Benedetti F, et al. (1998) Polymorphism within the promoter of the serotonin transporter gene and antidepressant efficacy of fluvoxamine. Mol Psychiatry 3: 508-511.

Snow V, Lascher S and Mottur-Pilson C. (2000) Pharmacologic treatment of acute major depression and dysthymia. American College of Physicians-American Society of Internal Medicine. Ann Intern Med 132: 738-742.

StataCorp. (2013) Stata Statistical Software: Release 13. College Station, TX: StataCorp LP.

Steffens DC, Svenson I, Marchuk DA, et al. (2002) Allelic differences in the serotonin transporter-linked polymorphic region in geriatric depression. Am J Geriatr Psychiatry 10: $185-191$.

Stroup DF, Berlin JA, Morton SC, et al. (2000) Meta-analysis of Observational Studies in Epidemiology: A Proposal for Reporting. JAMA 283: 2008-2012.

Sullivan PF, Neale MC and Kendler KS. (2000) Genetic epidemiology of major depression: review and meta-analysis. Am J Psychiatry 157: 1552-1562.

Thompson M, Gonzalez N, Nguyen T, et al. (2000) Serotonin transporter gene polymorphisms in alcohol dependence. Alcohol 22: 61-67.

Tiihonen J, Kuikka JT, Bergstr^m KA, et al. (1997) Single-photon emission tomography imaging of monoamine transporters in impulsive violent behaviour. Eur J Nucl Med 24: $1253-1260$. 
Wendland JR, Moya PR, Kruse MR, et al. (2008) A novel, putative gain-of-function haplotype at SLC6A4 associates with obsessive-compulsive disorder. Hum Mol Genet 17: $717-723$.

Wieser T, Dresler K, Evers S, et al. (2010) No influence of 5-HTTLPR gene polymorphism on migraine symptomatology, comorbid depression, and chronification. Headache 50: 420430.

Williams JW, Mulrow CD, Chiquette E, et al. (2000) A systematic review of newer pharmacotherapies for depression in adults: evidence report summary. Ann Intern Med 132: $743-756$.

World Health Organization. (1992) The ICD-10 Classification of Mental and Behavioural Disorders: Clinical descriptions and diagnostic guidelines, Geneva: World Health Organization.

Young-Wolff KC, Enoch MA and Prescott CA. (2011) The influence of gene-environment interactions on alcohol consumption and alcohol use disorders: a comprehensive review. Clin Psychol Rev 31: 800-816.

Zanardi R, Benedetti F, DiBella D, et al. (2000) Efficacy of paroxetine in depression is influenced by a functional polymorphism within the promoter of serotonin transporter gene. J Clin Psychopharmacol 20: 105-107. 
Table 1 Selection Criteria for cases and controls in the studies included in the meta-analysis for associations of 5HTTLPR polymorphism with (i) major depressive disorder without alcohol dependence, and (ii) alcohol dependence without major depressive disorder.

\begin{tabular}{|c|c|c|c|c|c|c|c|c|}
\hline Study & Year & Country & Sex & $\begin{array}{l}\text { Diagnostic } \\
\text { Criteria }\end{array}$ & Selection of Cases & $\begin{array}{l}\text { Age of cases, years } \\
\text { (mean (SD)/ } \\
\text { median (range)/ } \\
\text { range) }\end{array}$ & Selection of Controls & $\begin{array}{l}\text { Age of controls, } \\
\text { years } \\
\text { (mean (SD)/ } \\
\text { median (range)/ } \\
\text { range) }\end{array}$ \\
\hline & \multicolumn{8}{|c|}{ (i) Studies of major depressive disorder without alcohol dependence } \\
\hline $\begin{array}{l}\text { Collier et al., } \\
1996\end{array}$ & 1996 & $\begin{array}{l}\text { England, } \\
\text { Germany, } \\
\text { Italy }\end{array}$ & Both & $\begin{array}{l}\text { DSM-IV } \\
\text { (England, } \\
\text { Germany) } \\
\text { DSM-III-R } \\
\text { (Italy) }\end{array}$ & $\begin{array}{l}\text { Patients from Lithium therapy clinics } \\
\text { at the Department of Chemical } \\
\text { Pathology, The Institute of Psychiatry, } \\
\text { Epsom General Hospital and Northern } \\
\text { General Hospital, Sheffield in } \\
\text { England (n=86); Department of } \\
\text { Psychiatry, University of Wurzburg in } \\
\text { Germany ( }=47) \text {; and inpatient } \\
\text { departments of Hospital San Faffaele, } \\
\text { Milan in Italy }(n=22) \text {. }\end{array}$ & NA & $\begin{array}{l}\text { Unrelated Caucasian volunteers } \\
\text { with no history of major psychiatric } \\
\text { or neurological illness from GP } \\
\text { surgery in SE London }(n=187) \text { and } \\
\text { King's College Hospital }(n=83) \text {, } \\
\text { England or Caucasian blood donors } \\
\text { from Germany }(n=301) \text { and Italy } \\
(n=95) \text {. }\end{array}$ & NA \\
\hline $\begin{array}{l}\text { Kunugi et } \\
\text { al., } 1997\end{array}$ & 1997 & Japan & Both & DSM-IV & $\begin{array}{l}49(16 \mathrm{M}, 33 \mathrm{~F}) \text { patients from general } \\
\text { psychiatric clinics of Teikyo } \\
\text { University Hospital, Showa University } \\
\text { Hospital and Shiga University of } \\
\text { Medical Science Hospital, Tokyo. }\end{array}$ & $58(13)$ & $\begin{array}{l}212(99 \mathrm{M}, 113 \mathrm{~F}) \text { healthy } \\
\text { volunteers who were medical } \\
\text { students and hospital staff. }\end{array}$ & $32(13)$ \\
\hline $\begin{array}{l}\text { Rees et al., } \\
1997\end{array}$ & 1997 & England & Males & DSM-IV & $\begin{array}{l}54 \text { patients from a Lithium clinic and } \\
\text { psychiatric outpatient referrals in } \\
\text { South Wales. }\end{array}$ & $\begin{array}{l}57 \text { (13) for Lithium } \\
\text { clinic patients } \\
42(12) \text { for } \\
\text { psychiatric } \\
\text { outpatients referrals }\end{array}$ & $\begin{array}{l}121(52 \mathrm{M}, 69 \mathrm{~F}) \text { unrelated } \\
\text { Caucasian blood donors from South } \\
\text { Wales }\end{array}$ & $44(11)$ \\
\hline $\begin{array}{l}\text { Furlong et } \\
\text { al., } 1998\end{array}$ & 1998 & UK & Both & DSM-IV & $\begin{array}{l}125(47 \mathrm{M}, 78 \mathrm{~F}) \text { Caucasian patients } \\
\text { from in-patient and out-patient clinics } \\
\text { in East Anglia. }\end{array}$ & NA (18-65) & $\begin{array}{l}\text { Anonymous East Anglian } \\
\text { population from the Molecular } \\
\text { Genetics Laboratory, } \\
\text { Addenbrooke's Hospital DNA } \\
\text { bank, matched for age and sex to } \\
\text { cases. }\end{array}$ & NA \\
\hline $\begin{array}{l}\text { Gutierrez et } \\
\text { al., } 1998\end{array}$ & 1998 & Spain & Both & DSM-IV & $\begin{array}{l}74(17 \mathrm{M}, 57 \mathrm{~F}) \text { patients from the } \\
\text { Mental Health Service in the }\end{array}$ & $60.3(12.5)$ & $\begin{array}{l}84(32 \mathrm{M}, 52 \mathrm{~F}) \text { unrelated controls, } \\
\text { geographically matched, the general }\end{array}$ & NA \\
\hline
\end{tabular}


Eixample district of Barcelona.

$\begin{array}{llll}\begin{array}{l}\text { Hoehe et al., } 1998 \text { France } \quad \text { Both } \quad \text { DSM-IV } \\ 1998\end{array} & \begin{array}{l}36 \text { patients from two hospitals in } \\ \text { Rouffach, Alsace, and in Marseilles, }\end{array}\end{array}$

West European descent.

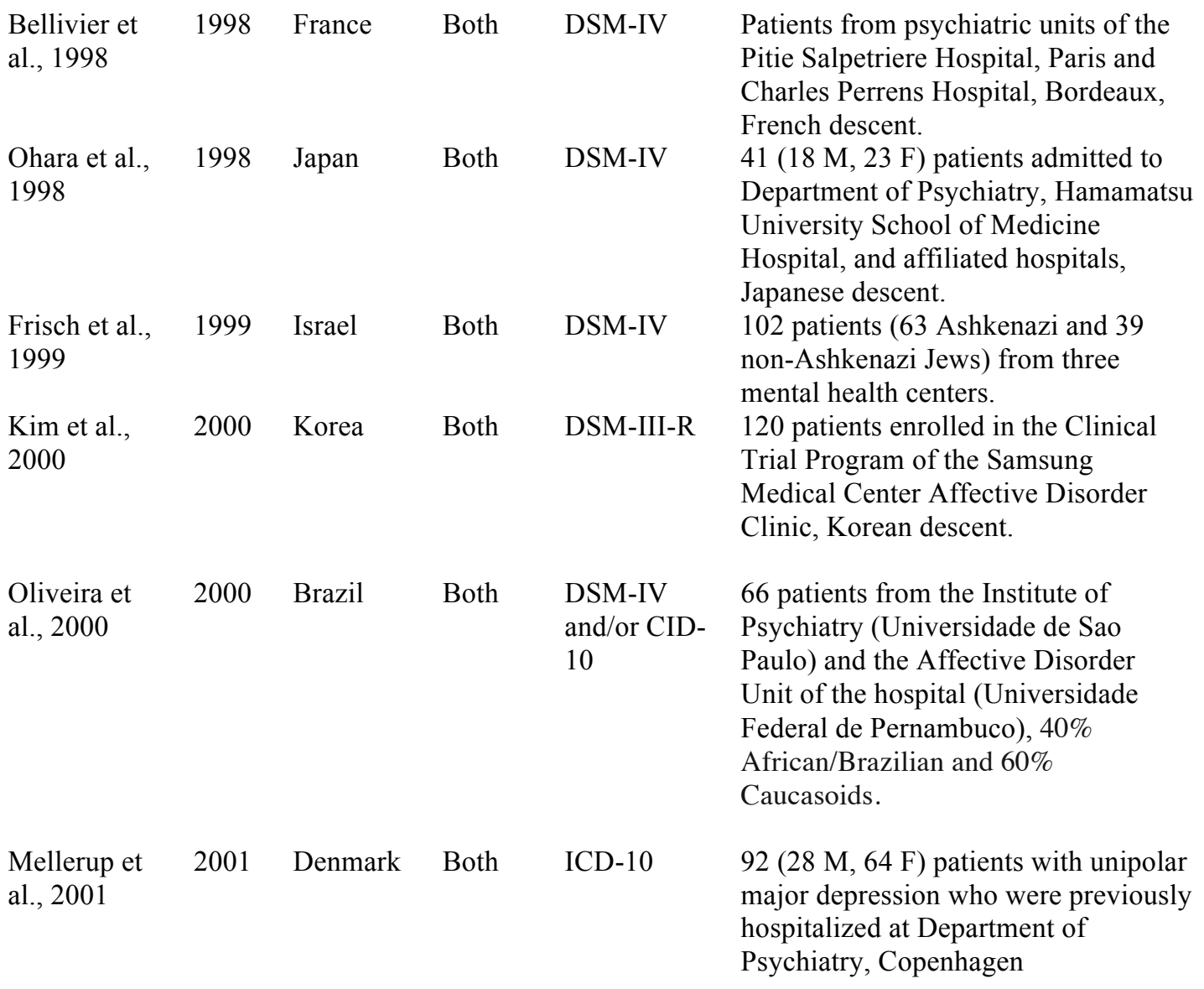

population of Barcelona.

NA Healthy staff and students without a history of mood disorders from

Rouffach, Alsace ( $\mathrm{n}=73)$, and

Berlin ( $n=208)$, West European

descent.

NA Blood donors at the Pitie

Salpetriere Hospital, French

descent.

$42.6(16.0)$

$92(37 \mathrm{M}, 55 \mathrm{~F})$ healthy unrelated medical staff and students living in the same area as the patients, with

no history of psychiatric diseases or psychotic medications.

NA Mentally and physically healthy controls (112 Ashkenazi and 60 non-Ashkenazi Jews).

54.2 (15.9) 252 healthy volunteers with no history of psychiatric illness from Samsung Biomedical Research Institute and Samsung Medical Center.

41.3 (11.4) Volunteer normal controls with no familial or personal history of psychiatric disorder or treatment working at the Sao Paulo

University or normal relatives of muscular dystrophy patients $(\mathrm{n}=152)$, and from the Federal

University of Pernambuco $(n=45)$.

$53(18-86) \quad 108(30 \mathrm{M}, 78 \mathrm{~F})$ healthy hospital and university staff and from health

NA

retiree club members 
Minov et al., 2001 Germany Both DSM-IV $173(59 \mathrm{M}, 114 \mathrm{~F})$ patients from

Steffens et

2002 USA

Both

al., 2002

Serretti et

2002 Italy

al., 2002

Arias et al., $2003 \quad$ Spain

2003

Hauser et al., 2003 Poland

2003

Frodl et al., 2004 Germany Both 2004

Hoefgen et 2005 Germany Both al., 2005
CES-D

Department of Psychiatry, Ludwig-

Maximilians University of Munich.

Patients with coexisting substance

abuse or severe organic disorders were excluded.

$182(69 \%$ F) geriatric patients

(inpatients and outpatients) with

clinically significant depressive

symptoms or previously diagnosed

mood disorder, recruited from the

Mental Health Clinic Research Centre

of the Duke University.

$667(58 \% \mathrm{~F})$ inpatients admitted to the

Department of Psychiatry at the

Institute H. San Raffaele. Patients

with concomitant diagnoses of mental

together with somatic or neurological

illnesses that impaired psychiatric

evaluation were excluded.

131 (31 M, $100 \mathrm{~F}$ ) outpatients from

the Centre de Salut Mental Esquerre

de 1'Eixample (Hospital Cl1'nic i

Provincial de Barcelona)

$94(25 \mathrm{M}, 68 \mathrm{~F})$ inpatients from the

Department of Adult Psychiatry,

University of Medical Sciences in

Poznan and at the Department of

Psychiatry, Pomeranian Academy of

Medicine in Szczecin

DSM-IV 40 inpatients from the Department of

Psychiatry at Ludwig-Maximilians-

University, Munich. Patients with

previous alcohol or substance abuse or neurologic diseases were excluded.

DSM-IV

and/or

(161 M, $305 \mathrm{~F})$ patients admitted

DSM-III-R

to the Department of Psychiatry at the University of Bonn retardation or drug dependence,
$49.9(14)$

$121(60 \mathrm{M}, 61 \mathrm{~F})$ healthy

general population in southern

Germany with no severe physical or

psychiatric axis I or axis II

disorders.

$69.6(59-96) \quad 107(64 \%$ F) controls recruited

from the Center for Aging Subject

Registry at Duke University. No

neurologic or depressive illness.

$46(14.4)$

$457(51 \% \mathrm{~F})$ healthy unrelated

individuals recruited from healthy

department personnel and people

attending the general lab of the

Institute H. San Raffaele, only

individuals with negative family

history included, Italian descent.

$39.9(12.3) \quad 163(83 \mathrm{M}, 80 \mathrm{~F})$ healthy unrelated controls from the same geographic and ethnic origin as the patients.

50 (11) $213(131 \mathrm{M}, 82 \mathrm{~F})$ blood donors who were not psychiatrically screened.

44.4 (11.7) $\quad 40$ healthy individuals from the Munich population, who were matched with age, sex, and

handedness to cases.

$50.9(14.7) \quad 836(376 \mathrm{M}, 460 \mathrm{~F})$ controls randomly selected from the list of registered inhabitants of Bonn (North Rhine-Westphalia) individuals recruited from the

$47.3(10.5)$

$70.2(58-92)$ 


\begin{tabular}{|c|c|c|c|c|c|}
\hline $\begin{array}{l}\text { Cervilla et } \\
\text { al., } 2006\end{array}$ & 2007 & Spain & Both & ICD-10 & $\begin{array}{l}737(208 \mathrm{M}, 529 \mathrm{~F}) \text { patients attending } \\
\text { primary care centres in the area of } \\
\text { Malaga, who involved in a genetic } \\
\text { association study called PREDICT } \\
\text { study }\end{array}$ \\
\hline $\begin{array}{l}\text { Dorado et } \\
\text { al., } 2007\end{array}$ & 2007 & Spain & Both & DSM-IV & $\begin{array}{l}70(23 \mathrm{M}, 47 \mathrm{~F}) \text { outpatients from a } \\
\text { mental health center, Servicio } \\
\text { Extremen o de Salud,. }\end{array}$ \\
\hline $\begin{array}{l}\text { Hickie et al., } \\
2007\end{array}$ & 2007 & Australia & Both & DSM-IV & $\begin{array}{l}45(15 \mathrm{M}, 30 \mathrm{~F}) \text { patients from tertiary } \\
\text { referral services in South Eastern } \\
\text { Sydney. Patients with major } \\
\text { depression secondary to a major } \\
\text { medical illness were excluded. }\end{array}$ \\
\hline $\begin{array}{l}\text { Wieser et al., } \\
2010\end{array}$ & 2010 & Germany & Both & $\begin{array}{l}\text { BDI or } \\
\text { CES-D }\end{array}$ & $\begin{array}{l}\text { Patients from three university-based } \\
\text { headache clinics (Departments of } \\
\text { Neurology of the Universities of } \\
\text { Vienna, Münster, and Halle). Patients } \\
\text { with either mild or clinically relevant } \\
\text { depression were included. }\end{array}$ \\
\hline
\end{tabular}

49.1 (15.2) European primary-care attendees

51 (14) $\quad 142(71$ M, 71 F) Spanish healthy controls from the same

geographical region

$52.0(12.8) \quad 16(7 \mathrm{M}, 9 \mathrm{~F})$ healthy controls recruited from community via local newspaper advertisement

43.3 (12.1) Age- and sex-matched participants from the headache prevalence study

\section{(ii) Studies of alcohol dependence without major depressive disorder}

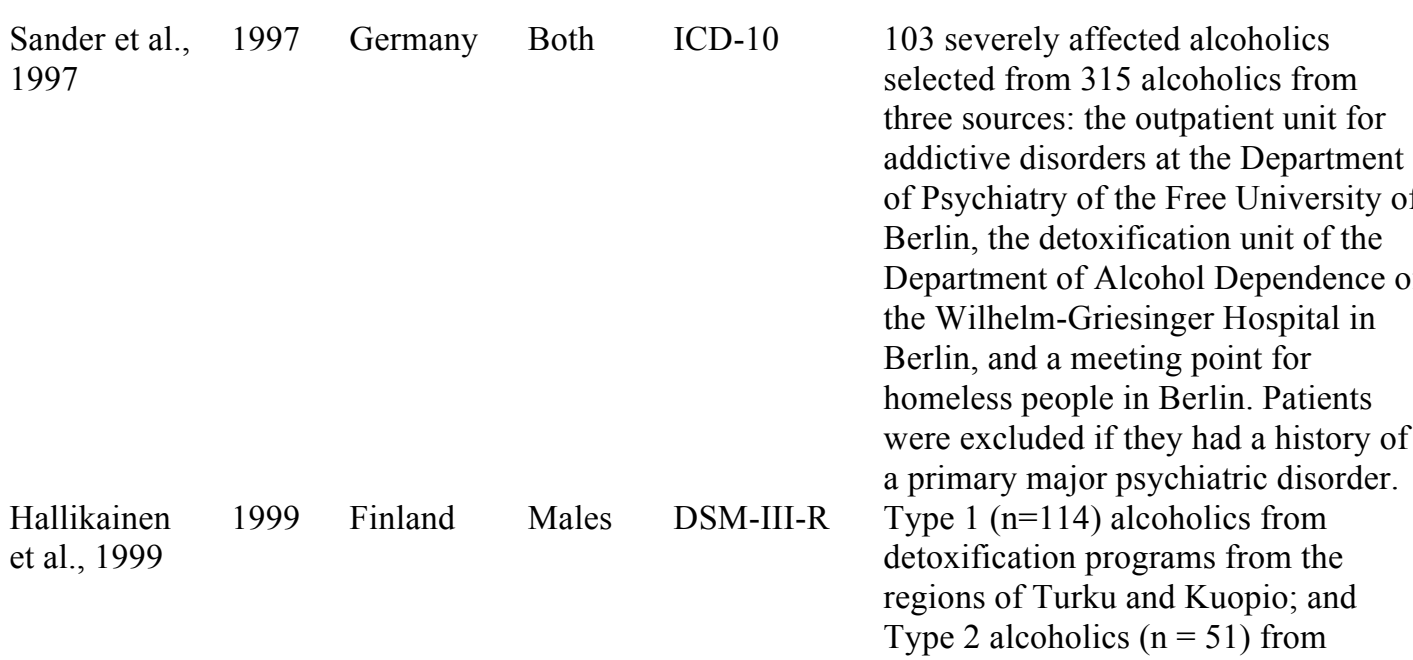

43.8 (8.8) for Type 1 Employees of two industrial alcoholics corporations in two cities in

30.1 (8.4) for Type 2 Southern Finland recruited via alcoholics occupational health services donors without psychiatric assessment $(\mathrm{n}=105)$ and controls who were older than 26 years, without a history of an addictive disorder or previous psychiatric treatment $(\mathrm{n}=111)$ 
forensic psychiatric examination in a

state mental hospital, Kuopio

\begin{tabular}{|c|c|c|c|c|c|}
\hline $\begin{array}{l}\text { Hammoumi } \\
\text { et al., } 1999\end{array}$ & 1999 & France & Both & $\begin{array}{l}\text { Short } \\
\text { MAST } \\
\text { criteria }\end{array}$ & $\begin{array}{l}104 \text { unrelated Caucasians of French } \\
\text { origin, recruited in hospitals } \\
\text { specialized in alcohol therapeutics. } \\
\text { Patients with depression disorder were } \\
\text { excluded. }\end{array}$ \\
\hline $\begin{array}{l}\text { (Matsushita } \\
\text { et al., 2001) }\end{array}$ & 2001 & Japan & Males & DSM-III-R & $\begin{array}{l}166(153 \mathrm{M}, 13 \mathrm{~F}) \text { unrelated Japanese } \\
\text { alcoholic patients with histories of } \\
\text { withdrawal seizure or delirium, } \\
\text { selected based on hospital records, } \\
\text { from patients receiving treatment at } \\
\text { one of seven hospitals in Japan. } \\
\text { Patients with major psychiatric } \\
\text { disorders were excluded. } \\
692 \text { alcoholics patients from the } \\
\text { National Institute on Alcoholism }\end{array}$ \\
\hline $\begin{array}{l}\text { Thompson et } \\
\text { al., } 2000\end{array}$ & 2000 & Canada & Both & DSM-IV & $\begin{array}{l}131 \text { patients from The Center for } \\
\text { Addiction and Mental Health } \\
\text { (CAMH), Toronto, and the City } \\
\text { ofHope National Medical Center } \\
\text { (COH), Duarte, CA. Patients had no } \\
\text { other psychiatric disorder. }\end{array}$ \\
\hline $\begin{array}{l}\text { Gorwood et } \\
\text { al., } 2000\end{array}$ & 2000 & France & Males & DSM-III-R & $\begin{array}{l}110 \text { male alcoholics from two general } \\
\text { hospitals in Paris, French origin, no } \\
\text { comorbid dementia, no schizophrenia, } \\
\text { no bipolar manic depressive disorder. } \\
\text { Alcoholic patients without major } \\
\text { depressive disorders were only } \\
\text { included in this meta-analysis ( } n=83) \text {. }\end{array}$ \\
\hline $\begin{array}{l}\text { Preuss et al., } \\
2001\end{array}$ & 2001 & Germany & Both & $\begin{array}{l}\text { DSM-IV or } \\
\text { ICD-10 }\end{array}$ & $\begin{array}{l}163(131 \mathrm{M}, 32 \mathrm{~F}) \text { Caucasian patients } \\
\text { recruited from an addiction treatment } \\
\text { ward with diagnosis of alcohol } \\
\text { dependence. Alcoholic patients } \\
\text { without major depressive disorders } \\
\text { were only included in this meta- }\end{array}$ \\
\hline
\end{tabular}

$43.57(1.43)$

38 blood donors from Centre

Régional de Transfusion Sanguine

Bois-Guillaume

$52.2(9.4) \quad 213$ age- and sex-matched unrelated, healthy Japanese individuals with no documented

neuropsychiatric disorders

$50.5(9.7) \quad 270$ unrelated male non-alcoholic Japanese controls, mainly hospital employee or persons connected with them, age-mated to cases

30-55 125 controls of Northern European descent from CAMH, Toronto, admitted for medical treatment not related to alcohol dependence and having no history of psychiatric treatment or substance dependence.

70 male controls from a blood transfusion center, at least 35 years old and French origin, without any substance dependence
$43.8(2.65)$ 
analysis $(n=105)$.

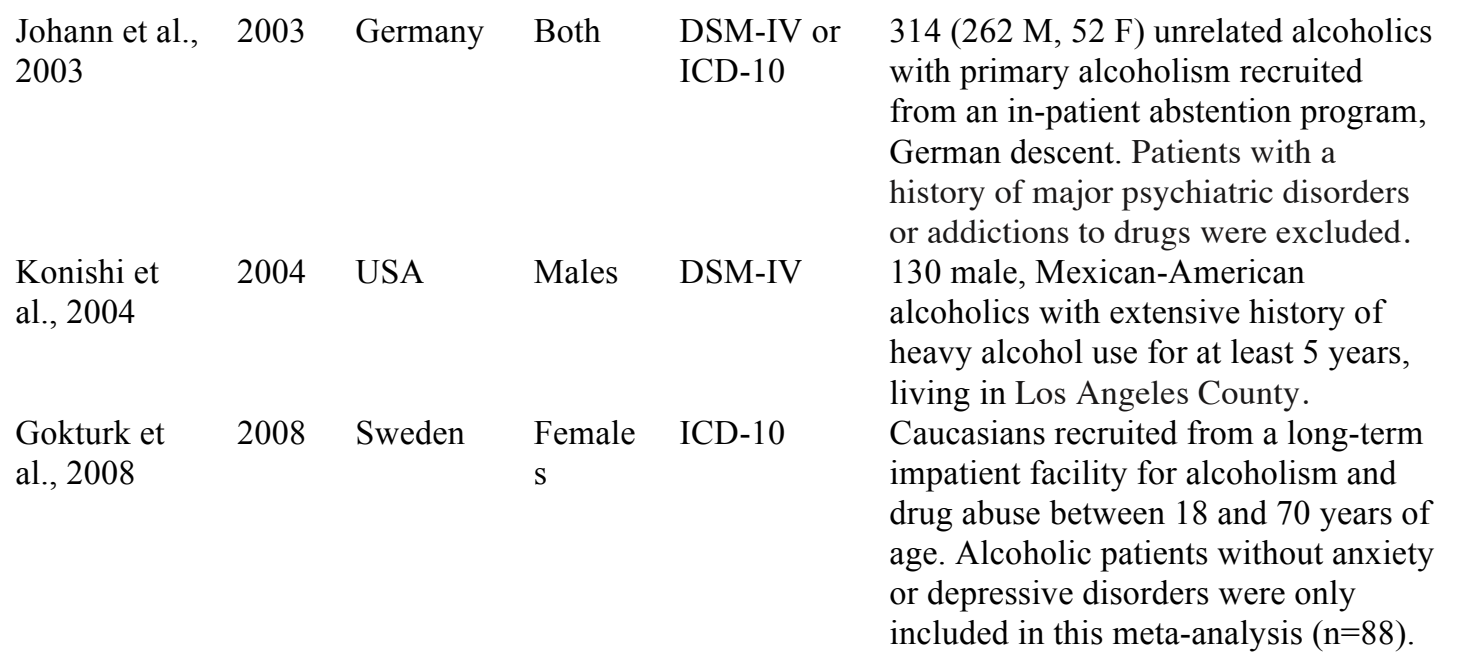

$43.1(18-72)$

220 unrelated healthy individuals of German descent, residents in the

same area as cases, without an addictive of major psychiatric disorder or previous psychiatric treatment.

$38.2(11.8) \quad 251(105 \mathrm{M}, 146 \mathrm{~F})$ healthy

volunteer controls, living in Los Angeles County.

18-75 631 controls randomly selected from high school students, $80 \%$ response rate included in this meta-analysis $(\mathrm{n}=88)$

BDI, Beck Depression Inventory; CES-D, Center for Epidemiologic Studies Depression Scale; DSM-IV, Diagnostic and Statistical Manual of

Mental Disorders Fourth Edition; DSM-III-R, Diagnostic and Statistical Manual of Mental Disorders Third Edition Revised; ICD-10,

International Classification of Disease - 10th revision; MAST, Michigan Alcoholism Screening Test; NA, not available. 
Table 2 Distribution of 5HTTLPR genotype for cases and controls in the studies included in the meta-analysis for associations of 5HTTLPR polymorphism with (i) major depressive disorder without alcohol dependence and (ii) alcohol dependence without major depressive disorder.

\begin{tabular}{|c|c|c|c|c|c|c|}
\hline \multirow{2}{*}{ Study } & \multicolumn{2}{|c|}{ SS } & \multicolumn{2}{|c|}{ SL } & \multicolumn{2}{|c|}{$\mathbf{L L}$} \\
\hline & Case & Control & Case & Control & Case & Control \\
\hline \multicolumn{7}{|c|}{ (i) Studies of major depressive disorder without alcohol dependence } \\
\hline Collier et al., (1996) & 41 & 101 & 63 & 278 & 46 & 191 \\
\hline Rees et al. (1997) & 13 & 24 & 35 & 59 & 32 & 35 \\
\hline Furlong et al. (1998) & 26 & 29 & 64 & 81 & 35 & 59 \\
\hline Gutierrez et al. (1998) & 14 & 17 & 41 & 37 & 15 & 29 \\
\hline Ohara et al. (1998) & 26 & 54 & 13 & 32 & 2 & 6 \\
\hline Frisch et al. (1999) & 22 & 39 & 50 & 96 & 30 & 37 \\
\hline Kim et al. (2000) & 68 & 137 & 47 & 103 & 5 & 12 \\
\hline Oliveira et al. (2000) & 14 & 32 & 28 & 87 & 24 & 78 \\
\hline Mellerup et al. (2001) & 16 & 18 & 40 & 53 & 36 & 37 \\
\hline Minov et al. (2001) & 40 & 17 & 79 & 64 & 53 & 40 \\
\hline Frodl et al. (2004) & 8 & 10 & 16 & 17 & 16 & 13 \\
\hline Hoefgen et al. (2005) & 99 & 127 & 222 & 406 & 141 & 294 \\
\hline Cervilla et al. (2006) & 133 & 101 & 205 & 246 & 106 & 129 \\
\hline Dorado et al. (2007) & 17 & 26 & 40 & 71 & 13 & 45 \\
\hline Hickie et al. (2007) & 12 & 3 & 18 & 5 & 15 & 8 \\
\hline Wieser et al. (2010) & 14 & 34 & 52 & 88 & 43 & 61 \\
\hline TOTAL & 834 & 1121 & 1568 & 2438 & 990 & 1534 \\
\hline
\end{tabular}


(ii) Studies of alcohol dependence without major depressive disorder

\begin{tabular}{|c|c|c|c|c|c|c|}
\hline Sander et al. (1997) & 27 & 35 & 44 & 100 & 32 & 81 \\
\hline Hallikainen et al. (1999) & 45 & 8 & 55 & 20 & 65 & 26 \\
\hline Hammoumi et al. (1999) & 25 & 4 & 43 & 14 & 34 & 20 \\
\hline Ishiguro et al. (1999) & 114 & 201 & 46 & 81 & 6 & 8 \\
\hline Matsushita et al. (2001) & 459 & 179 & 212 & 83 & 21 & 8 \\
\hline Thompson et al. (2000) & 35 & 19 & 53 & 55 & 43 & 51 \\
\hline Gorwood et al. (2000) & 15 & 11 & 41 & 26 & 27 & 24 \\
\hline Preuss et al. (2001) & 18 & 18 & 50 & 58 & 37 & 41 \\
\hline Johann et al. (2003) & 52 & 35 & 154 & 116 & 108 & 69 \\
\hline Konishi et al. (2004) & 49 & 77 & 62 & 111 & 19 & 63 \\
\hline Gokturk et al. (2008) & 15 & 133 & 33 & 285 & 40 & 213 \\
\hline TOTAL & 854 & 720 & 793 & 949 & 432 & 604 \\
\hline
\end{tabular}


Table 3 Meta-analysis summary odds ratios (ORs) and their 95\% confidence intervals (CIs) for associations between different genotypes of 5HTTLPR polymorphism and the risk of major depressive disorder without alcohol dependence and the risk of alcohol dependence without major depressive disorder

\begin{tabular}{ccccc} 
& \multicolumn{1}{c}{ Fixed effect } & Random effects & \multicolumn{2}{c}{ Heterogeneity } \\
\cline { 2 - 5 } & OR (95\% CI) & OR (95\% CI) & $\mathbf{I}^{\mathbf{2}} \mathbf{( \% )}$ & $\boldsymbol{p}$-value \\
\hline $\begin{array}{c}\text { Major depressive disorder } \\
\text { without alcohol dependence }\end{array}$ & & & \\
\hline Recessive (SS vs. SL+LL) & $1.33(1.19-1.48)$ & $1.33(1.19-1.48)$ & 0.1 & 0.46 \\
Dominant (SS+SL vs. LL) & $1.12(1.01-1.24)$ & $1.11(0.97-1.26)$ & 30.0 & 0.09 \\
Codominant & & & \\
SS vs. LL & $1.36(1.19-1.56)$ & $1.32(1.10-1.57)$ & 28.5 & 0.10 \\
SL vs. LL & $1.03(0.93-1.15)$ & $1.03(0.90-1.17)$ & 20.7 & 0.18 \\
Per S allele & $1.16(1.08-1.23)$ & $1.14(1.05-1.24)$ & 29.3 & 0.09 \\
\hline $\begin{array}{c}\text { Alcohol dependence without } \\
\text { major depressive disorder }\end{array}$ & & & \\
\hline Recessive (SS vs. SL+LL) & $1.18(1.01-1.38)$ & $1.22(1.00-1.49)$ & 30.3 & 0.16 \\
Dominant (SS+SL vs. LL) & $1.11(0.94-1.32)$ & $1.16(0.91-1.47)$ & 46.0 & 0.05 \\
Codominant & & & & \\
SS vs. LL & $1.33(1.06-1.66)$ & $1.36(0.99-1.87)$ & 47.6 & 0.04 \\
SL vs. LL & $1.02(0.86-1.23)$ & $1.04(0.85-1.27)$ & 15.9 & 0.29 \\
Per S allele & $1.12(1.01-1.23)$ & $1.14(0.98-1.32)$ & 51.3 & 0.02 \\
\hline
\end{tabular}

OR: odds ratio; CI confidence interval; $\mathrm{I}^{2}$ : \% residual variation due to heterogeneity. 
Table 4 Meta-regression models for associations between recessive inheritance of the $\mathrm{S}$ allele of 5HTTLPR polymorphism (SS vs SL+LL) and the risk of major depressive disorder without alcohol dependence and the risk of alcohol dependence without major depressive disorder

\begin{tabular}{|c|c|c|c|c|c|c|}
\hline & $\begin{array}{l}\text { Number } \\
\text { of } \\
\text { studies } \\
\end{array}$ & $\begin{array}{l}\text { Fixed effect model } \\
\text { Summary OR } \\
(95 \% \text { CI }) \\
\end{array}$ & $\mathbf{I}^{2}(\%)$ & $\tau^{2}$ & $\begin{array}{l}\text { Ratio of ORs } \\
(95 \% \text { CI }) \\
\end{array}$ & $p$-value \\
\hline \multicolumn{7}{|l|}{$\begin{array}{l}\text { Major depressive disorder } \\
\text { without alcohol dependence }\end{array}$} \\
\hline \multicolumn{7}{|l|}{ Population } \\
\hline Caucasians & 18 & $1.36(1.20,1.54)$ & 0.29 & 0.001 & 1.00 & - \\
\hline Others & 5 & $1.18(0.90,1.54)$ & & & $0.86(0.63,1.18)$ & 0.34 \\
\hline \multicolumn{7}{|l|}{ Year of publication } \\
\hline Before and in 2000 & 11 & $1.23(1.02,1.49)$ & 0.30 & 0.001 & 1.00 & - \\
\hline After 2000 & 12 & $1.38(1.20,1.59)$ & & & $1.12(0.87,1.44)$ & 0.35 \\
\hline \multicolumn{7}{|l|}{ Diagnostic Criteria } \\
\hline DSM-IV criteria & 18 & $1.34(1.17,1.53)$ & 4.46 & 0.01 & 1.00 & \\
\hline Others & 5 & $1.31(1.06,1.61)$ & & & $0.96(0.72,1.29)$ & 0.80 \\
\hline \multicolumn{7}{|l|}{$\begin{array}{l}\text { Alcohol dependence without } \\
\text { major depressive disorder }\end{array}$} \\
\hline \multicolumn{7}{|l|}{ Population } \\
\hline Caucasians & 8 & $1.33(1.06,1.68)$ & 27.6 & 0.02 & 1.00 & - \\
\hline Others & 3 & $1.07(0.86,1.32)$ & & & $0.80(0.50,1.27)$ & 0.30 \\
\hline \multicolumn{7}{|l|}{ Year of publication } \\
\hline Before and in 2000 & 6 & $1.43(1.11,1.85)$ & 17.0 & 0.02 & 1.00 & - \\
\hline After 2000 & 5 & $1.05(0.86,1.28)$ & & & $0.71(0.46,1.10)$ & 0.11 \\
\hline \multicolumn{7}{|l|}{ Diagnostic Criteria } \\
\hline DSM-IV criteria & 5 & $1.20(0.96,1.50)$ & 37.1 & 0.04 & 1.00 & \\
\hline Others & 6 & $1.16(0.93,1.44)$ & & & $1.01(0.61,1.68)$ & 0.96 \\
\hline
\end{tabular}

OR: odds ratio; CI confidence interval; DSM IV: Diagnostic and Statistical Manual of Mental Disorders Fourth Edition; $\mathrm{I}^{2}: \%$ residual variation due to heterogeneity; $\tau^{2}$, residual maximum likelihood estimate of between-study variance. 
Figure 1 Flow diagram of the selection of studies

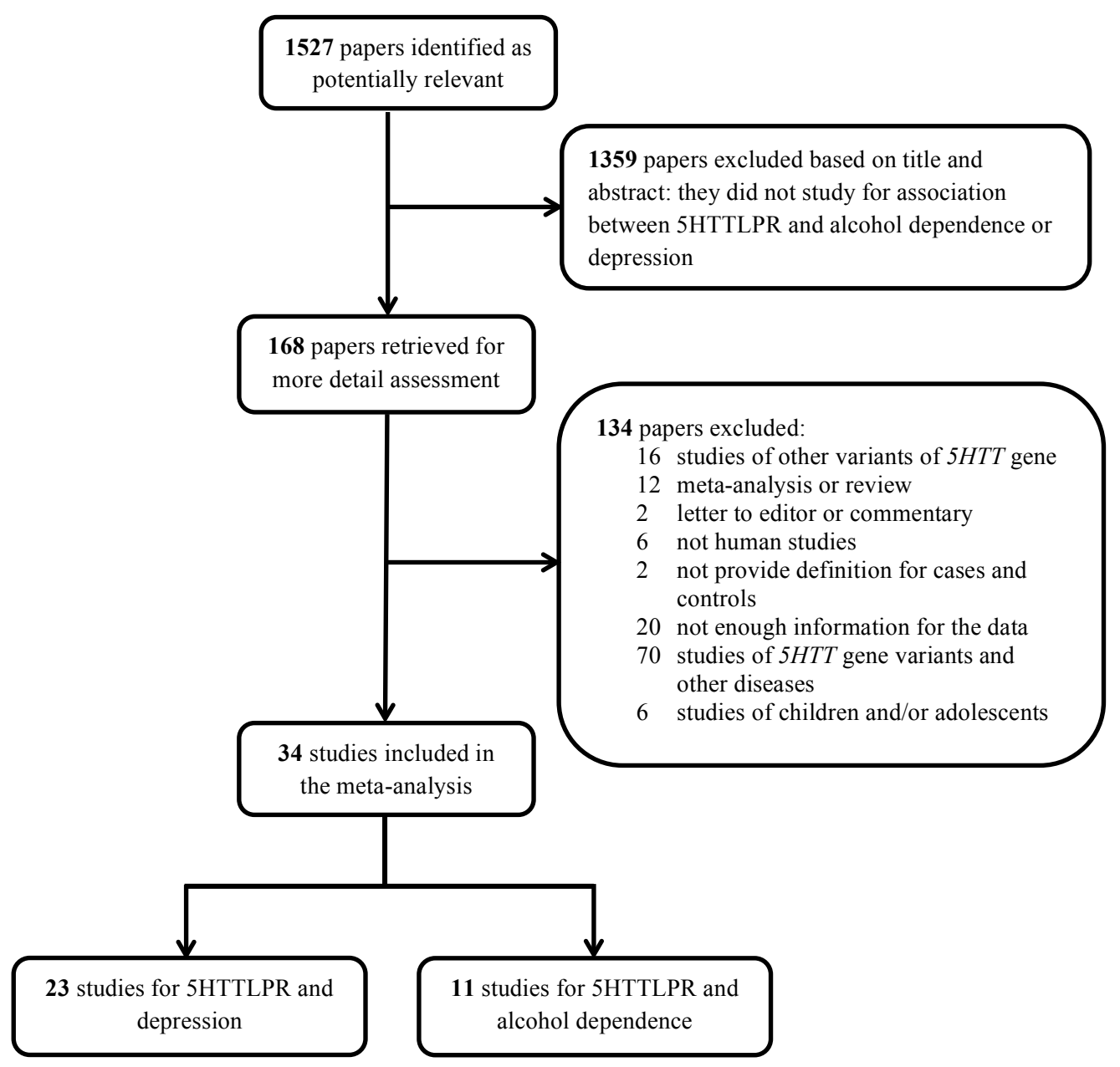


Figure 2 Begg's funnel plots for publication bias for studies of (A) major depressive disorder without alcohol dependence and (B) alcohol dependence without major depressive disorder. OR, odds ratio, $\mathrm{SE}$, standard error.
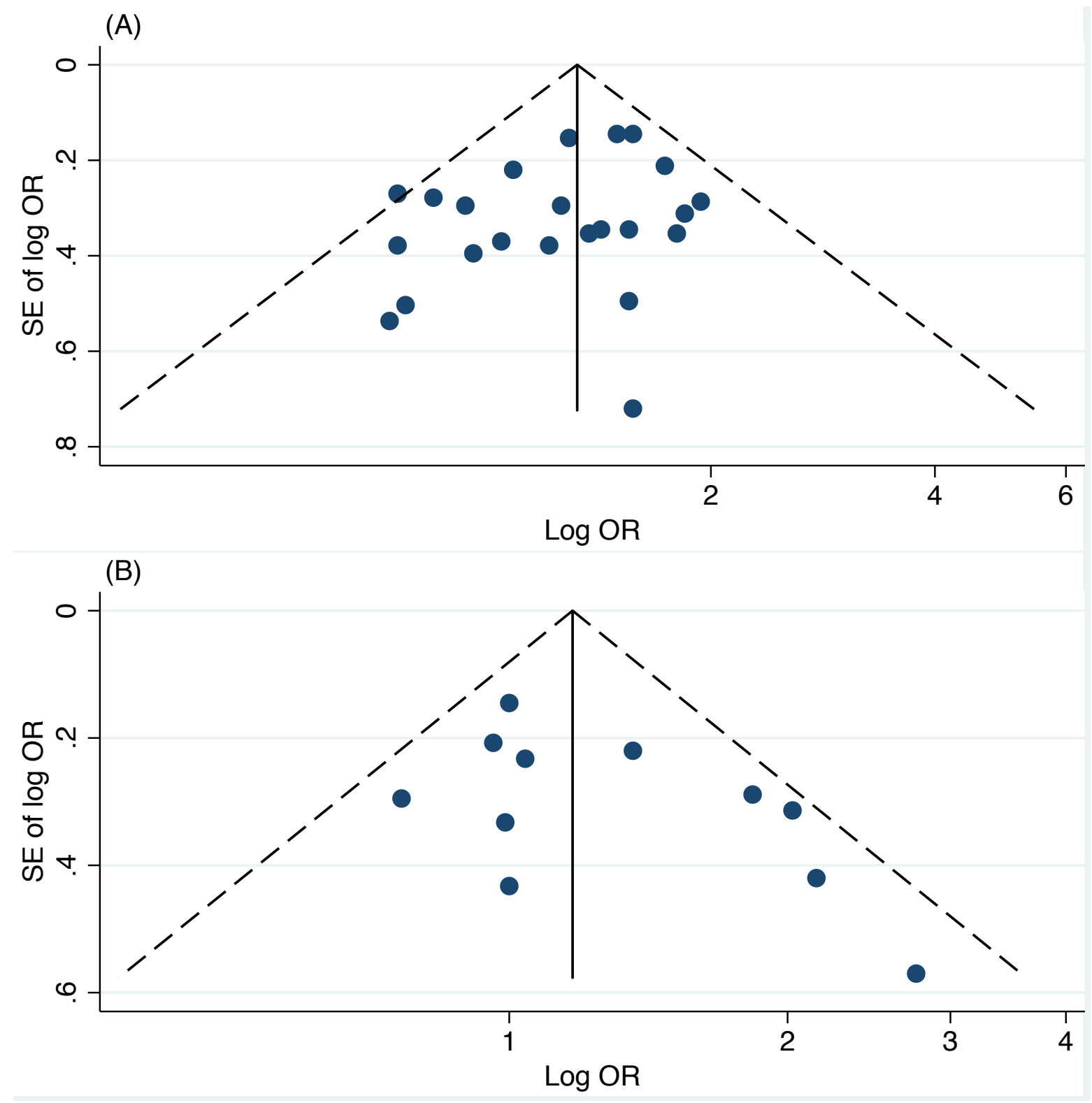
Supplementary Figure 1 Meta-analysis of associations between recessive inheritance of the S allele of 5HTTLPR polymorphism (SS vs SL+LL) and the risk of major depressive disorder and alcohol dependence

SS vs SL+LL

\begin{tabular}{|c|c|c|c|}
\hline Study & Sex & OR $(95 \% \mathrm{Cl})$ & $\%$ Weight \\
\hline \multicolumn{4}{|c|}{ Depression without Alcohol Dependence } \\
\hline Collier et al. (1996) & $\mathrm{M}, \mathrm{F}$ & $1.75(1.15,2.65)$ & 7.18 \\
\hline Kunugi et al. (1997) & $\mathrm{M}, \mathrm{F}$ & $1.57(0.79,3.15)$ & 2.61 \\
\hline Rees et al. (1997) & M & $0.76(0.36,1.60)$ & 2.27 \\
\hline Furlong et al. (1998) & $\mathrm{M}, \mathrm{F}$ & $1.27(0.70,2.28)$ & 3.63 \\
\hline Gutierrez et al. (1998) & $\mathrm{M}, \mathrm{F}$ & $0.97(0.44,2.14)$ & 2.01 \\
\hline Hoehe et al. (1998) & $\mathrm{M}, \mathrm{F}$ & $0.78(0.29,2.12)$ & 1.27 \\
\hline Bellivier et al. (1998) & $M, F$ & $1.57(0.59,4.15)$ & 1.33 \\
\hline Ohara et al. (1998) & $M, F$ & $1.22(0.57,2.61)$ & 2.18 \\
\hline Frisch et al. (1999) & $M, F$ & $0.94(0.52,1.69)$ & 3.59 \\
\hline Kim et al (2000) & $\mathrm{M}, \mathrm{F}$ & $1.10(0.71,1.70)$ & 6.56 \\
\hline Oliveria et al. (2000) & $\mathrm{M}, \mathrm{F}$ & $1.39(0.69,2.80)$ & 2.56 \\
\hline Mellerup et al. (2001) & $\mathrm{M}, \mathrm{F}$ & $1.05(0.50,2.20)$ & 2.30 \\
\hline Minov et al. (2001) & $M, F$ & $1.85(0.99,3.46)$ & 3.24 \\
\hline Steffens et al. (2002) & $M, F$ & $1.82(0.90,3.69)$ & 2.52 \\
\hline Serretti et al. (2002) & $\mathrm{M}, \mathrm{F}$ & $1.29(0.95,1.76)$ & 12.97 \\
\hline Arias et al. (2003) & $M, F$ & $0.85(0.49,1.49)$ & 4.04 \\
\hline Hauser et al. (2003) & $\mathrm{M}, \mathrm{F}$ & $1.94(1.09,3.47)$ & 3.75 \\
\hline Frodi et al. (2004) & $M, F$ & $0.75(0.26,2.15)$ & 1.13 \\
\hline Hoefgen et al. (2005) & $M, F$ & $1.50(1.12,2.01)$ & 14.78 \\
\hline Cervilla et al. (2007) & $\mathrm{M}, \mathrm{F}$ & $1.59(1.18,2.14)$ & 14.05 \\
\hline Dorado et al. (2007) & $M, F$ & $1.43(0.72,2.86)$ & 2.62 \\
\hline Hickie et al. (2007) & $\mathrm{M}, \mathrm{F}$ & $1.58(0.38,6.51)$ & 0.63 \\
\hline Wieser et al. (2010) & $\mathrm{M}, \mathrm{F}$ & $0.65(0.33,1.27)$ & 2.77 \\
\hline \multicolumn{2}{|c|}{ Fixed Effect $(I-$ squared $=0.1 \%, p=0.459)$} & $1.33(1.19,1.48)$ & 100.00 \\
\hline Random Effects & & $1.33(1.19,1.48)$ & \\
\hline \multicolumn{4}{|c|}{ Alcohol Dependence without Depression } \\
\hline Sander et al. (1997) & $\mathrm{M}, \mathrm{F}$ & $1.84(1.04,3.25)$ & 7.55 \\
\hline Hallikainen et al. (1999) & M & $2.16(0.94,4.92)$ & 3.59 \\
\hline Hammoumi et al. (1999) & $M, F$ & $2.76(0.89,8.54)$ & 1.91 \\
\hline Ishiguro et al. (1999) & $\mathrm{M}, \mathrm{F}$ & $0.97(0.64,1.47)$ & 14.38 \\
\hline Thompson et al. (2000) & $M, F$ & $2.03(1.09,3.79)$ & 6.29 \\
\hline Gorwood et al. (2000) & M & $1.00(0.42,2.37)$ & 3.31 \\
\hline Matsushita et al. (2001) & M & $1.00(0.74,1.35)$ & 27.60 \\
\hline Preuss et al. (2001) & $\mathrm{M}, \mathrm{F}$ & $1.14(0.56,2.32)$ & 4.79 \\
\hline Johann et al. (2003) & $\mathrm{M}, \mathrm{F}$ & $1.05(0.66,1.68)$ & 11.15 \\
\hline Konishi et al. (2004) & $\mathrm{M}, \mathrm{F}$ & $1.37(0.88,2.13)$ & 12.35 \\
\hline Gokturk et al. (2008) & $\mathrm{F}$ & $0.77(0.43,1.38)$ & 7.08 \\
\hline \multicolumn{2}{|c|}{ Fixed Effect (I-squared $=30.3 \%, p=0.157)$} & $1.18(1.01,1.38)$ & 100.00 \\
\hline Random Effects & & $1.22(1.00,1.49)$ & \\
\hline
\end{tabular}


Supplementary Figure 2 Meta-analysis of associations between dominant inheritance of the $\mathrm{S}$ allele of 5HTTLPR polymorphism (SS+SL vs LL) and the risk of major depressive disorder and alcohol dependence

SS+SL vS LL

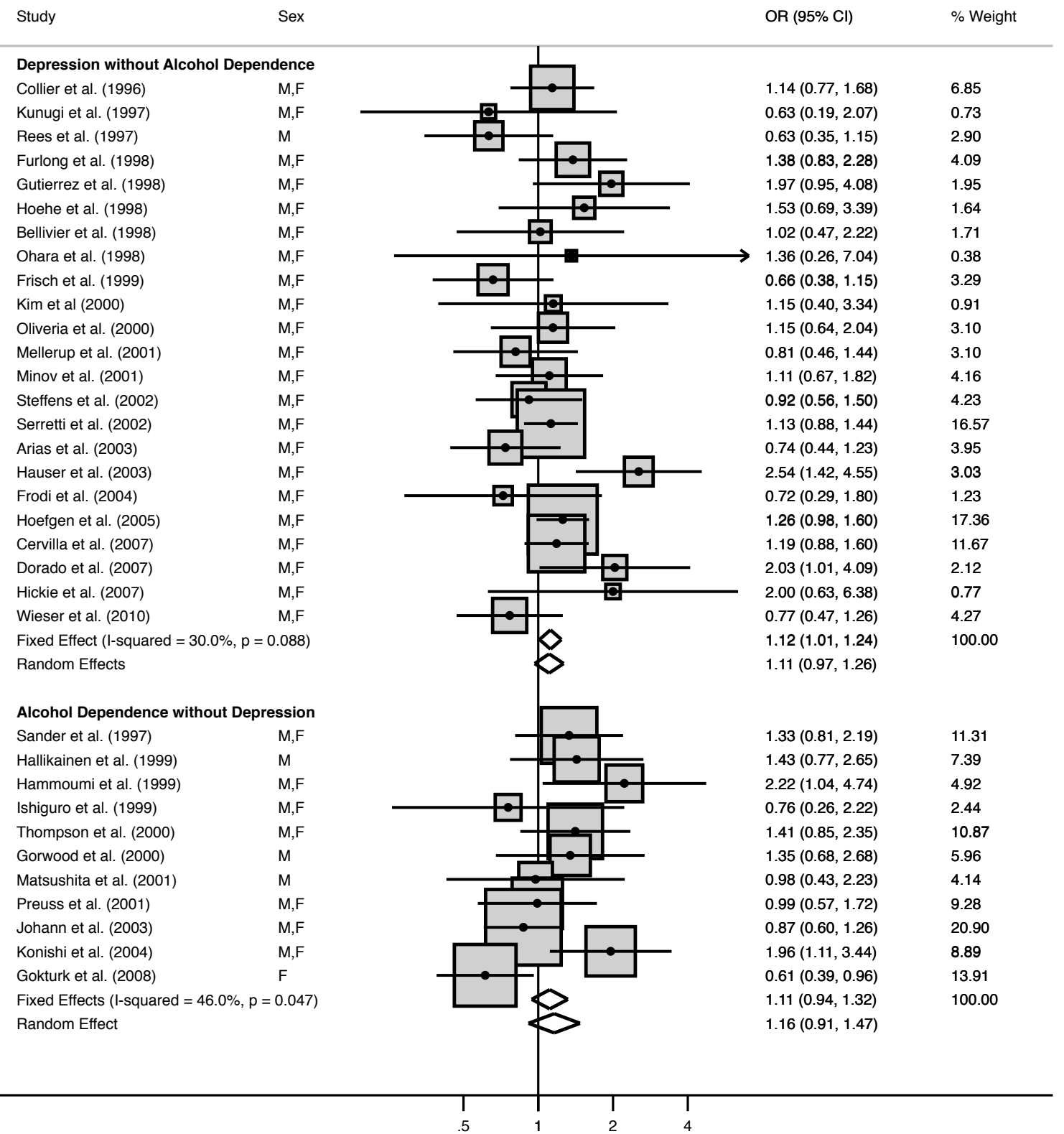


Supplementary Figure 3 Meta-analysis of the risk of major depressive disorder and alcohol dependence for homozygous carriers of the S allele of 5HTTLPR polymorphism compared with non-carriers (SS vs LL)

SS vs LL

Study

OR $(95 \% \mathrm{Cl})$

$\%$ Weight

Depression without Alcohol Dependence

Collier et al. (1996)

Kunugi et al. (1997)

Rees et al. (1997)

Furlong et al. (1998)

Gutierrez et al. (1998)

Hoehe et al. (1998)

Bellivier et al. (1998)

Ohara et al. (1998)

Frisch et al. (1999)

Kim et al (2000)

Oliveria et al. (2000)

Mellerup et al. (2001)

Minov et al. (2001)

Steffens et al. (2002)

Serretti et al. (2002)

Arias et al. (2003)

Hauser et al. (2003)

Frodi et al. (2004)

Hoefgen et al. (2005)

Cervilla et al. (2007)

Dorado et al. (2007)

Hickie et al. (2007)

$M, F$

$\mathrm{M}, \mathrm{F}$

$M, F$

$\mathrm{M}, \mathrm{F}$

$M, F$

$M, F$

$M, F$

Wieser et al. (2010)

$\mathrm{M}, \mathrm{F}$

Fixed Effect $(I-$ squared $=30.0 \%, p=0.088)$

Random Effects

Alcohol Dependence without Depression

Sander et al. (1997)

Hallikainen et al. (1999)

Hammoumi et al. (1999)

Ishiguro et al. (1999)

Thompson et al. (2000)

Gorwood et al. (2000)

Matsushita et al. (2001)

Preuss et al. (2001)

$M, F$

Johann et al. (2003)

Konishi et al. (2004)

$M, F$

Gokturk et al. (2008)

$\mathrm{M}, \mathrm{F}$

Fixed Effect (I-squared $=47.6 \%, p=0.039$ )

Random Effects

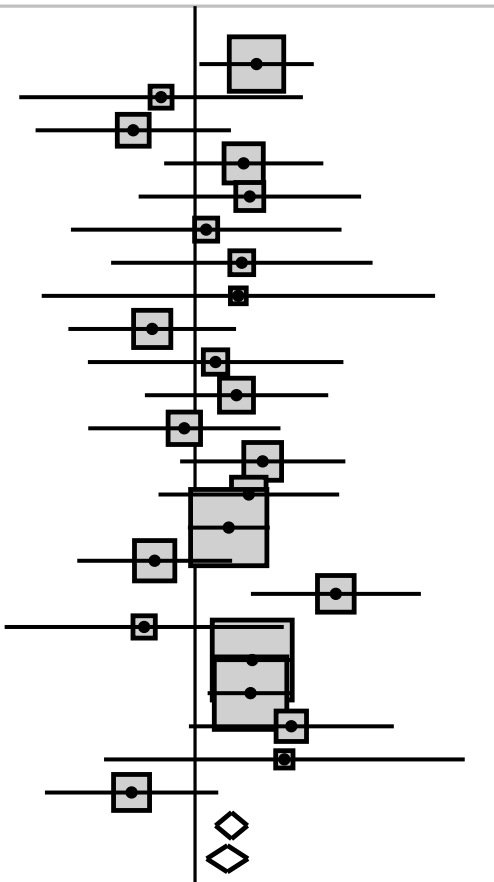

$1.69(1.04,2.74)$

$0.75(0.23,2.50)$

$0.59(0.26,1.36)$

$1.51(0.77,2.97)$

$1.59(0.62,4.09)$

$1.10(0.35,3.46)$

$1.49(0.49,4.50)$

$1.44(0.27,7.65)$

$0.70(0.34,1.42)$

$1.19(0.40,3.52)$

$1.42(0.65,3.09)$

$0.91(0.40,2.06)$

$1.78(0.88,3.58)$

$1.58(0.73,3.40)$

$1.33(0.94,1.88)$

$0.71(0.37,1.37)$

$3.30(1.61,6.79)$

$0.65(0.20,2.12)$

$1.63(1.17,2.26)$

$1.60(1.11,2.31)$

$2.26(0.95,5.40)$

$2.13(0.46,9.84)$

$0.58(0.28,1.22)$

$1.36(1.19,1.56)$

$1.32(1.10,1.57)$

$1.95(1.02,3.73)$

$2.25(0.93,5.42)$

$3.68(1.12,12.10)$

$0.76(0.26,2.23)$

$2.18(1.10,4.36)$

$1.21(0.47,3.14)$

$0.98(0.42,2.25)$

$1.11(0.50,2.44)$

$0.95(0.56,1.60)$

$2.11(1.13,3.94)$

$0.60(0.32,1.13)$

$1.33(1.06,1.66)$

$1.36(0.99,1.87)$
7.73

1.26

2.66

4.00

2.05

1.38

1.48

0.65

3.60

1.55

3.01

2.74

3.71

3.10

15.14

4.22

3.51

1.30

16.64

13.69

2.41

0.78

3.37

100.00

11.81

6.42

3.49

4.22

10.40

5.46

7.15

7.94

18.03

12.66

12.42

100.00 
Supplementary Figure 4 Meta-analysis of the risk of major depressive disorder and alcohol dependence for heterozygous carriers of the S allele of 5HTTLPR polymorphism compared with non-carriers (SL vs LL)

\section{SL vs LL}

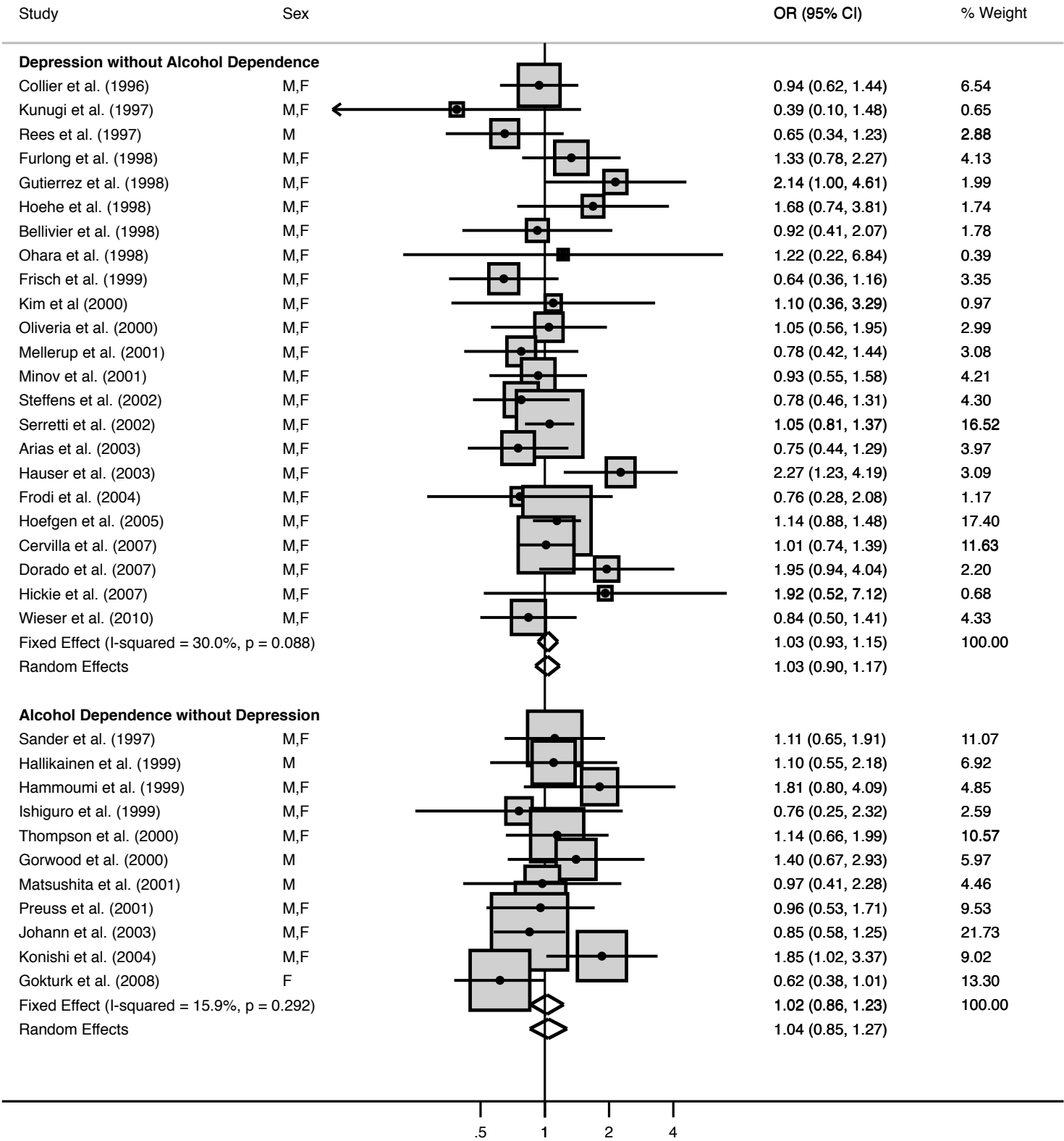


Supplementary Figure 5 Meta-analysis of per allele association between the S allele of 5HTTLPR polymorphism and the risk of major depressive disorder and alcohol dependence

per S allele

\begin{tabular}{|c|c|c|c|}
\hline Study & Sex & OR $(95 \% \mathrm{Cl})$ & $\%$ Weight \\
\hline \multicolumn{4}{|c|}{ Depression without Alcohol Dependence } \\
\hline Collier et al. (1996) & $\mathrm{M}, \mathrm{F}$ & $1.28(0.99,1.64)$ & 6.78 \\
\hline Kunugi et al. (1997) & $M, F$ & $1.22(0.71,2.11)$ & 1.43 \\
\hline Rees et al. (1997) & M & $0.75(0.50,1.12)$ & 2.59 \\
\hline Bellivier et al. (1998) & $\mathrm{M}, \mathrm{F}$ & $1.16(0.67,2.02)$ & 1.41 \\
\hline Furlong et al. (1998) & $\mathrm{M}, \mathrm{F}$ & $1.24(0.89,1.73)$ & 3.89 \\
\hline Gutierrez et al. (1998) & $M, F$ & $1.31(0.83,2.08)$ & 2.01 \\
\hline Hoehe et al. (1998) & $M, F$ & $1.13(0.68,1.86)$ & 1.69 \\
\hline Ohara et al. (1998) & $M, F$ & $1.19(0.64,2.22)$ & 1.11 \\
\hline Frisch et al. (1999) & $M, F$ & $0.82(0.57,1.18)$ & 3.30 \\
\hline Kim et al (2000) & $M, F$ & $1.09(0.75,1.58)$ & 3.05 \\
\hline Oliveria et al. (2000) & $M, F$ & $1.17(0.80,1.72)$ & 2.89 \\
\hline Mellerup et al. (2001) & $M, F$ & $0.92(0.62,1.37)$ & 2.75 \\
\hline Minov et al. (2001) & $M, F$ & $1.26(0.90,1.76)$ & 3.87 \\
\hline Serretti et al. (2002) & $M, F$ & $1.14(0.96,1.35)$ & 15.22 \\
\hline Steffens et al. (2002) & $M, F$ & $1.12(0.79,1.58)$ & 3.64 \\
\hline Arias et al. (2003) & $M, F$ & $0.84(0.60,1.16)$ & 3.99 \\
\hline Hauser et al. (2003) & $M, F$ & $1.82(1.28,2.59)$ & 3.45 \\
\hline Frodi et al. (2004) & $M, F$ & $0.80(0.45,1.44)$ & 1.25 \\
\hline Hoefgen et al. (2005) & $M, F$ & $1.26(1.07,1.48)$ & 16.06 \\
\hline Cervilla et al. (2007) & $M, F$ & $1.27(1.05,1.52)$ & 12.89 \\
\hline Dorado et al. (2007) & $M, F$ & $1.51(0.99,2.30)$ & 2.39 \\
\hline Hickie et al. (2007) & $\mathrm{M}, \mathrm{F}$ & $1.52(0.71,3.27)$ & 0.73 \\
\hline Wieser et al. (2009) & $\mathrm{M}, \mathrm{F}$ & $0.78(0.55,1.10)$ & 3.59 \\
\hline \multicolumn{2}{|c|}{ Fixed Effect $(1-$ squared $=30.0 \%, p=0.088)$} & $1.16(1.08,1.23)$ & 100.00 \\
\hline Random Effects & & $1.14(1.05,1.24)$ & \\
\hline \multicolumn{4}{|c|}{ Alcohol Dependence without Depression } \\
\hline Sander et al. (1997) & $\mathrm{M}, \mathrm{F}$ & $1.37(0.99,1.90)$ & 9.51 \\
\hline Hallikainen et al. (1999) & M & $1.42(0.95,2.13)$ & 6.17 \\
\hline Hammoumi et al. (1999) & $\mathrm{M}, \mathrm{F}$ & $1.89(1.10,3.24)$ & 3.44 \\
\hline Ishiguro et al. (1999) & $M, F$ & $0.95(0.67,1.35)$ & 7.98 \\
\hline Gorwood et al. (2000) & M & $1.15(0.72,1.83)$ & 4.61 \\
\hline Thompson et al. (2000) & $\mathrm{M}, \mathrm{F}$ & $1.43(1.02,2.00)$ & 8.98 \\
\hline Matsushita et al. (2001) & M & $1.00(0.77,1.30)$ & 14.90 \\
\hline Preuss et al. (2001) & $M, F$ & $1.03(0.71,1.51)$ & 6.93 \\
\hline Johann et al. (2003) & $M, F$ & $0.95(0.74,1.22)$ & 15.82 \\
\hline Konishi et al. (2004) & $M, F$ & $1.40(1.04,1.88)$ & 11.47 \\
\hline Gokturk et al. (2008) & $\mathrm{F}$ & $0.74(0.54,1.01)$ & 10.19 \\
\hline \multicolumn{2}{|c|}{ Fixed Effect $(I-$ squared $=51.3 \%, p=0.024)$} & $1.12(1.01,1.23)$ & 100.00 \\
\hline Random Effects & & $1.14(0.98,1.32)$ & \\
\hline
\end{tabular}

